Journal of Applied Finance \& Banking, Vol. 11, No. 2, 2020, 29-93

ISSN: 1792-6580 (print version), 1792-6599(online)

https://doi.org/10.47260/jafb/1122

Scientific Press International Limited

\title{
The Nexus Between Internal Investment and Economic Growth in Kenya
}

\author{
Andrew K. Kamenju' and Dr. T. Olweny ${ }^{2}$
}

\begin{abstract}
Countries with a high investment GDP ratio benefit from better, competitive products and services. Which increases capital stock for production, more employment, and income; in turn reducing social and income disparities. The Kenyan government envisaged a sustained economic growth of $10 \%$ by investing in priority sectors; to become an industrialized middle-income country by the year 2030; though un-achieved to date. To examine the nexus between internal investments and economic growth, the study used annual time-series observations from the years 1996 to 2017; where internal investments are from the government; private domestic; and public-private partnership; and exogenous variables were rates of real interest; social discount; commercial lending interest; and the country risk premium on lending for investment decisions. The inference used stationarity; cointegration; significance; causality; variance decomposition of forecast error; and impulse response function. Stationarity tests suited the ARDL model which also supports small size observations. Findings were; a significant and positive influence on economic growth from lags of real GDP, government, private domestic, except public-private partnership investments. Anticipation for growth lies with; significant pairwise causality (real GDP with public investment); significant block exogeneity (public investment); endogeneity (real GDP), and exogeneity (public investment) influence; and short-run private domestic investment recovery.
\end{abstract}

Keywords: ARDL, Economic Growth, Public Investment, Private Domestic Investment, Public-Private Partnership Investment, Investment Decisions.

\footnotetext{
1 1Msc Student, Department of Economics, Accounting and Finance (KSMS), Jomo Kenyatta University of Agriculture and Technology, Kenya.

2 2Department of Economics, Accounting and Finance, Jomo Kenyatta University of Agriculture and Technology, Nairobi, Kenya.
}

Article Info: Received: October 13, 2020. Revised: November 25, 2020.

Published online: December 1, 2020. 


\section{Introduction}

\subsection{Background}

In the Kenyan context, the linkages and relationship between internal investments and economic growth are important in informing government policies that would raise the standards of living and social welfare of its citizens. According to Bakari (2017), investments are critical to economies' realization of economic growth because they affect the size of capital stock; productive capacity; employment; inflation; income, and national output. Those countries with higher investment/GDP ratio boost competitiveness, generate employment, and reduces social and income disparities, and lead to higher economic growth (UNCTAD, 2010; Anwar \& Sampath, 1999). From this perspective, this study uses "Internal investments" to imply domestic investments both public and private that are real investments from 1) government, 2) private domestic investors and 3) public-private partnership investments. Therefore, for the study, this excludes foreign private investments in the form of foreign direct and indirect investments. According to Javid (2015) on economic growth, the nexus between output and investments suggest numerous direct and indirect transmission channels. Where direct channels are those resulting in the productivity of private inputs and the rate of return of private capital. Indirect channels as cost adjustments, labor productivity, and the durability of private capital, and economies of scale according to Javid (2015). Finally, Javid (2015) relates the relative impact of public and private investment crowding out or crowding in during the process of economic growth. These direct and indirect transmissions referred to by Javid (2015) forms the basis for the nexus between investments and economic growth. This is a feature Bakari (2017) states that makes researchers pay attention to the importance of economic, financial, and accounting terms when making investment decisions.

In investment decisions, "Social discount rates", "financial discount rates", and "hurdle interest rates" guide in discounting future benefits for the public, private domestic, and public-private partnership investments in that order. Guidance on investment decision-making considers the extent to which 1) risk-free interest rate, 2) risk premium, 3) market risk and 4) commercial banks lending interest rates are desirable for investment decisions. Of importance to note is that public investments with a too high social discount rate imply under-investment in social programs (smaller public sector) while a low social discount rate means over-investment (larger public sector) in respective countries (Koundouri, 2015). On public-private partnership investment, private companies before embarking on such public projects set up a hurdle interest rate based on the public project's nature of risk. It is from this hurdle rate that they compare with the project's internal rate of return. If viable, they adjust the hurdle rate using the asset-pricing theory model like the capital asset pricing model (CAPM) (Sharpe, 1964) to confirm its viability based on risk before making an investment decision. To avoid unreasonable discounting rates from public-private partnership investments, the Australian government recommends the use of CAPM to arrive at a favorable discounting rate (Finance 
Circular No. 2009/02, 2009). This intricate the dynamic linkage between social discount rates, market interest rates, and adjusted hurdle rates nexus between internal investments and economic growth. Hence, important to consider them as exogenous variables in the study. From this basis, in the process of aspiration for economic growth, crowding effects, causes within internal investments may affect the ultimate effect on economic growth.

Investment demand required for economic growth stands as an important factor in the behavior of standards of living in the long term and short term despite evidence of high volatility in the short-term. Secondly, investments make a dynamic element of GDP a measure of economic growth through its effect on capital stock. Where national output is $\mathrm{Y}=\mathrm{C}+\mathrm{I}+\mathrm{G}+(\mathrm{X}-\mathrm{M})$, I representing investment component. According to Ferrer and Zermeño (2015), investments in a closed economy are equal to savings. Savings originates from sacrificing present consumption for future investments in a country and is dependent on time preference. A factor considered in the social discount rate. However, in an open economy, investments and savings tend to be unequal. Implying domestic investment may be lower, equal, or higher than national savings (Ferrer and Zemeno, 2015). With unequal savings and investments in a country, external and internal borrowing bridges shortfall in investment demand financing. A new consideration that is gaining momentum in developing countries to bridge governments' budget deficit is public-private partnerships.

Return on investment expectations leads to more investments that raise the investment GDP ratio and lowers capital-output ratio from gross capital formation realized in a country. In the context of an open economy, stable interest rates and exchange rates help to build confidence and return expectations for investments (Pettinger, 2016). The cause for investment demand arising from consumption or income changes from internal or external balances, resulting in induced investment will require more investments to meet these short-run demand changes. Kenya in 2008 when it came up with Vision 2030 blueprint, envisaged a 10\% economic growth, and one of the focus areas was increasing internal investments through increased demand for goods and services arising from higher income.

While most developing countries look forward to economic growth, most of them are struggling with budgetary deficits, debt to GDP ratio, and investor's perception of project risks (Ketkar and Ratha, 2009). According to Ketkar and Ratha (2009), this means innovativeness to finance investments needed for economic growth. Kenya being among developing nations, in its aim in transforming to newly industrializing and a "middle-income country", improvement of quality of life for its citizens, it placed importance on internal investment development to achieve this by the year 2030. Elsewhere, OECD countries Committee on Financial Markets $(\mathrm{CMF})$ were considering the role of investments in economic growth in their 50th anniversary. The highlights of the meeting were assistance from the financial sector and academia to maintain economic growth in their member countries. This was to task the financial sector and academia to take a role in formulating policies to attract long-term investments, business innovativeness, and regulatory incentives. 
With such that these investments are devoid of short-termism. Besides, investments that could also offer beneficial risk-sharing in public investment projects through public-private partnership investments to change investment behavior in OECD countries (Wehinger, 2011).

\subsubsection{Public Investment}

What motivates public investment is the macroeconomic returns a country benefits from in the long term. Therefore, meaning public investments functionally relates to the public interest that a country would advance to its citizen's standards of living (Pan, 2016). The effect of public investment on economic growth according to Rabnawaz and Jafar (2015) tends to be specific to a country and affects economic growth differently. Public investments are large and have a high risk with the ultimate effect of raising output in the long-term. Besides responding to short-term demand effects when an economy is below full employment. The social discount rate is the interest rate according to Warusawitharana (2014) applied in cost-benefit analysis for public and infrastructure investment projects. This represents a reflection of society's relative valuation of current well-being versus the future's well-being time preference (Zhuang, Liang, Lin and Guzaman, 2007). Zhuag et al. (2007) further take caution in that if social discount rates were set too high, this precludes socially desirable public projects from implementation. On the other hand, if set too low, risks making many economically inefficient investments that are undesirable for economic growth impact. Regarding linkages between public and private investment, $\mathrm{Xu}$ and Yan (2014) confine to whether they are substitutes or complementary to economic growth. Xu and Yan (2014) on that basis argue that an increase in government investment directly or indirectly could crowd out private investment. The reason being the government's investment financing competes for funds in the capital market, which causes interest rates to rise therefore reducing loanable funds available to the private sector.

Nonetheless, according to Abiad, Furceri and Topalova (2015), public investment output effects depend on the degree of mediating factors such as; 1) degree of economic slack and monetary accommodation and 2) efficiency of public investments that would often lead to a decline in public debt GDP ratio when its debt-financed. Also, Oukhallou (2016) states that public investment projects selected on a profitability basis tend to increase output effects. From another angle, Ali (2015) associated output effects as the composite bundle of capital stock. A capital stock that augments expertise and technology of existing stock, a knowledge that comes together with public investments as the factors that contribute to output effects required for economic growth.

\subsubsection{Private Domestic Investments}

A characteristic of private domestic investment volume at any time in a country is the volatility situation during the boom and recession in a country. Such that during the slump, the volume of investments declines while investments rise during the 
boom (Pan, 2016). Fiscal and monetary stabilization policies applied in a country that affect interest rates help to reduce the volatility of investment volume. This is in that; sound policies give clear signals to the private sector's confidence (Ames, Brown, Devarajan, and Izquierdo (n.d.). Without macroeconomic stability, private domestic investors tend to stay away and divert their resources elsewhere due to uncertainty of the return on their investments (as cited by Ramey and Ramey, 1995). Also, conventional factors of real interest rates, private sector credit availability, and past economic growth influence the behavior of investments according to Ames et al. (n.d.).

\subsubsection{Public-Private Partnerships Investments (PPPs)}

World Bank defines public-private partnership investments (PPPs) as long-term contracts between a private party and a government entity for providing a public asset or service. The private party bears significant risk and is responsible for management and project performance. In furtherance of the execution of the contract for the provision of the public service or goods, remuneration for the private party is done through 1) compensation from a public fund, 2) charges or fees collected by the private party from users or consumers or 3) a combination of compensation and charges or fees. On the financing of public-private partnership investment, according to Klein (1997), comparing the cost of public capital and private capital is that even though the assumption that public capital is cheaper than private capital, it is difficult to compare the two based on public cost and private equity. According to Klein (1997), public capital should include the hidden risk premium of implicit guarantee to taxpayers for public debt with equivalent risk premium as built-in into the cost of private debt; and the opportunity cost for the country if that capital went to a different purpose. Klein (1997) under such circumstances cited an example from Chile; applying a "social discount rate" for capital on infrastructure compared to other sector's private equity cost of borrowing made it less likely to attract private financing. In such circumstances, Klein (1997) reiterates that this could result in less gross capital formation required for economic growth.

The first level to consider for a private party in investing in a project is the hurdle rate of return of the public project's internal rate of return. The hurdle rate of return takes into account, the shareholders' internal rate of return (Shareholder IRR), the return on equity (RoE), the project internal rate of return (Project IRR), and the return on capital employed (RoCE) (Sirtaine, Pinglo, Guasch and Foster, 2005). Where shareholder IRR and RoE are returns earned by equity investors. On the same, Project IRR and RoCE both are profitability of concessions on the project independent of financing structure. On the other hand, the government considers the gearing ratio when it comes to evaluating the financial health of the private party. The hurdle rate as the minimum rate of return on a project or investment, consideration by the private party would be risks, cost of capital, returns of similar investments, and anything else that may affect investment. Bearing in mind the 
internal rate of return of the project to the private party expectation is to be at least greater than the hurdle rate in the end. The CAPM model basis is that private party demands higher expected returns when they take on additional risk referred to above as the hurdle rate (Sirtaine et al., 2005). The extent to which the government considers such collaboration is if the cost-benefit accrued would outweigh social opportunity cost and to economic growth ultimately contribute at the end of an investment partnership.

\subsubsection{Global Investments Outlook}

According to IMF, World Economic Outlook Report (2014), a sample of countries taken from advanced economies showed a 1-percentage point of GDP increase in public investment spending increased the level of output by 0.4 percent in a year and 1.5 percent after four years. Regarding the investment effect on economic growth, the efficiency gap faced by developing countries was 40 percent, emerging markets 27 percent and in developed countries 13 percent (IMF World Economic Outlook, 2014). This represented a weak impact on the performance of investments required for economic growth in emerging and developing nations. This is an important concern to any government or investor if investment funds going to activities do not provide the greatest benefits to the society and return to the investor and implemented in the most efficient way (Koundouri, 2015). A case prevalent in developing and emerging markets.

Pan (2016) found in the process of China's economic development; public investment played an important role in stimulating economic growth by making the functioning of private investments more important. Fruman and Forneris (2016) attributed the same to a long-term vision and disciplined implementation. That had conducive targeting policies with the ability to harness the power of FDI for both inward and outward (domestic) investments. This helped to strengthen competitiveness for China's economy as a whole and its domestic firms. On publicprivate partnership investment according to Sarmento (2010) (as cited in Moralos and Amekudzi, 2008), they identified four procurement processes for public-private partnership investments. These as initial feasibility assessment, procurement phase, the construction phase, and operation, where evaluation for value for money was in the first phase as the most important for public-private partnership success. In Phase 2 of the process, it ensures the bids from the private sector are below the costs under traditional procurement. Sarmento (as cited Parker \& Hartley, 2003) study on some specific sectors in the United Kingdom that showed consistent results in the publicprivate partnership. Such that investment contracts achieved especially for defense services had cost savings of between 5\% and $40 \%$ compared to conventional public procurement.

\subsubsection{Africa's Investments Outlook}

According to the AfDB (2018) report, public investments rose steadily from the year 2000 to the year 2018 reaching 7.7 percent of GDP in Africa. This was more 
than Latin America at 5.2 percent and emerging and developing economies of Asia at 6.2 percent. In the same paper, AfDB further acknowledges in Africa, 12 million young people join the labor force every year with employment opportunities hardly available. From this, AfDB sees industrialization as one of the solutions to ending poverty and generating employment. Where industrialization retardation comes from the insufficient stock of productive infrastructure in power, water, and transport services. To AfDB, if there was enough and sufficient stock of productive infrastructure, it would encourage domestic investments needed to end poverty and generation of employment. According to AfDB 2018 report, as a continent, it needed USD 130 to 170 billion to finance public investments. With this need and a financing gap of between USD 68 to USD 108 billion, this could reverse the situation. It means African countries need to seek innovative ways to finance infrastructure projects required for economic growth like public-private partnership investment given this financing gap. An example of such a public-private partnership project innovation is a cooperation based on a 30-year build-operatetransfer concession of USD 660 million N4 Maputo Corridor Toll Road in this report. In this case, governments of South Africa and Mozambique jointly guaranteed debt to Trans African Concession (Pty) ltd consortium made of Trans African Concessions (Pty) Ltd (TRAC) with sixty percent AfDB, Standard Bank, and South African pension funds as shareholders for the financing of the project.

\subsubsection{Investments Perspective in Kenya}

It was the year 2014 that Kenya became a middle-income country through a publication in Kenya's Economic Survey Report from a preliminary revised GDP estimates of 2009 (rebase year). Using computed GNI for 2013; per capita income was USD 1,036.98 (constant 2010 USD) that surpassed the World Bank threshold of USD 1,036 for consideration in the middle-income bracket. In the year 2017, four years later, the population estimate for Kenya stood at 49 Million, had a per capita of GDP USD 1,790 with a USD 3,250 PPP (at constant USD 2005), and an economic growth rate of $4.9 \%$. Kenya's GDP composition based on a contribution from three broad sectors of agriculture, industry, and service was 35\%, $17.6 \%$, and $47.4 \%$ respectively. From empirical studies, increased internal investments play an essential role in promoting economic growth. Such that countries with higher investment/GDP ratio boost competitiveness, generate employment, and reduces social and income disparities and lead to higher economic growth (UNCTAD, 2010; Anwar \& Sampath, 1999). It is from this structure of the Kenyan economy's GDP composition that the encouragement of internal investment falls to address those with high marginal productivity propensity to meet the desired economic growth. On investment, according to the World Bank (2018) report, Kenya's public sector contribution to GDP growth, investments more than doubled from 1.1 to 2.5 percentage points of GDP between 2013 and 2017. The increase came from expansionary fiscal government consumption ( 0.4 percentage points) and public investment (1.0-percentage points). Most of it came from rolling out of devolution, 
new institutions under the new constitution, wage agitations, rising debt service, and pension liabilities. Unlike for public investment where there was expansion, private domestic investment declined from 1.3 percentage points of GDP to a negative 0.7 percentage. The decline in private domestic investment according to the World Bank (2018) was due to the crowding-out effect, the interest rate cap law in 2016 (now repealed (2019)), and political uncertainty leading to the 2017 general elections. On the positive side, there was an improved ranking of doing business with Kenya (80th out of 190 in the world) according to the World Bank, simplified procedures for business creation, and inclusion of public-private partnerships in the quest to achieve anticipated economic growth in its vision. There has also been notable evidence of gaining importance in the role of public-private partnership investments in Kenya. Some investment projects completed under public-private partnerships are like in energy (Olkaria) and transport infrastructure for the first phase of SGR. The second phase of SGR is under implementation; plans for a dual road of Mombasa to Nairobi, Lamu Port, and upgrade of several highways are also in the pipeline. The expected outcome of these projects would be to ease supplyside constraints to the economic growth of the country.

In summary, public investments that depend on social discount rates as the driver for boosting private domestic investments are yet to influence anticipated economic growth. Private domestic investments that depend on commercial bank's lending interest rates are yet too to influence the anticipated economic growth. Publicprivate partnership investments that depend on hurdle rate interest rates are yet too to impact on anticipated economic growth. In public-private partnership investments, there has been the case of implementation failures due to corruption and others placed on hold due to the debt level of the country.

\subsection{Statement of the problem}

Kenya has been struggling to attain an envisaged economic growth rate of $10 \%$ to achieve the status of an upper-middle-income industrialized country by the year 2030. To achieve this, Kenya identified six priority sectors to target with high potential for spurring economic growth, but it still yet to achieve this economic growth targeted. According to Kenya's Vision 2030 - Marking 10 years of progress 2008 - 2018 report on page 60, in MTP I (years 2008 to 2013), sectors of tourism, agriculture and livestock, wholesale and retail trade, manufacturing, business process outsourcing, and Financial Services, the government identified these sectors as the focus to achieve this envisaged economic growth. Later, the inclusion of oil and mineral resources sectors to make seven sectors MTP II (2013 to 2018) became part of the sectors to focus on. Investments in these sectors with the highest propensity for spurring economic growth became the attention to yield the economic growth envisaged. Despite the struggle to attain envisaged economic growth, there has been a positive impact in that national poverty level fell from $46 \%(2005 / 2006)$ to $36.1 \%(2015 / 2016)$, a great stride. However, if the economic growth rate trend remains the same as observed to date, over the remaining period, the achievement 
of the upper-middle-income country's vision would not be possible.

Central Bank interest rate in the year 2017 was around 10\%, infrastructure bond yields at $12 \%$, average commercial bank lending rates at $13.7 \%$, country risk lending premium of $5.3 \%$, and real interest rates at $2.78 \%$ according to Knoema data bank. Public investments depend on borrowing and taxes for financing, where borrowing competes for loanable funds in the money market with private domestic investments. According to World Bank Data for the year 2017, Kenya's gross capital formation was about $18.22 \%$ of GDP. Kenya at the same time had a declining gross domestic savings of $7.63 \%$ of GDP from previous years. There were seven hundred and sixty-four million USD in the year 2016 worth of investments under public-private partnership investments. Human capital index of 0.518 (out of 1) and CPIA transparency, accountability, and corruption index in public sector rating of three (range 1 (low) to 6 (high)). Indicators that influence attractiveness for investments like annual variation of consumption was about $7.0 \%$, investment variation of $6.3 \%$, and industrial production variation of $4.9 \%$ are higher in comparison to developed countries. These indicators are essential in how the linkages of internal investments could help to propel economic growth and investment efficiency.

Researchers on the linkage between internal investments and economic growth have not fully viewed relationships from economic, finance, and accounting terms perspective. In Kenya, research findings showed a positive relationship between public investments and economic growth (Maingi, 2017) as too several other studies considered (Ghani and Din, 2006; Rabnawaz and Jafar, 2015). However, there is a case of negative public investments influencing economic growth (Saidjada and Jahan, 2018) and private investments at the end in Pakistan. Besides this, in some countries, public and private domestic investments contribute differently in different countries (Zou, 2006; Makuyana and Odhiambo, 2018) and crowding effects (Xu and Yan, 2014). On private domestic investments, public domestic borrowing, monetary policy effects on interest rates, the dependence of the level of public investments affect economic growth (Lidiema (2017); Olweny and Chiluwe (2012). Public-private partnership investments studies also considered the crowding effect in both directions for public and private domestic investments, contribution to economic growth whose significances was based on the scale and efficiency (Pimentel et al. (2016); Zangoueinezhad and Azar (2014); Sarmento and Oliveira (2018); Jasiukevicius and Vasiliauskaite (2013); Song, Zhao, Jin, and Sun (2018)).

\subsection{Objectives of the Study}

\subsubsection{General Objective}

The study aims to determine the nexus between internal investments and economic growth from investments by the public, private domestic, and public-private partnerships in Kenya between the years 1996 and 2017. 


\subsubsection{Specific Objectives}

1. To determine the nexus between public investment and economic growth in Kenya.

2. To establish the nexus between private domestic investment and economic growth in Kenya.

3. To assess the nexus between public-private partnership investment and economic growth in Kenya.

\subsection{Research Hypotheses}

Ho1: Public investment has no relationship with economic growth in Kenya.

Ho2: Private Domestic investment has no relationship with economic growth in Kenya.

Ho3: Public-Private Partnership investment has no relationship with economic growth in Kenya.

\subsection{Significance of the Study}

Many transformative changes occurred within the last two decades in Kenya since the advent of a multiparty form of government. The intended results being for social, economic, and political space that would benefit and improve standards of living for all citizens. In the previous and current governments, emphases were and are still on public investments, especially in infrastructure projects in transport, energy, health, education, ICT, and water among other sectors. Again, and recently, interest control by CBK through capping of interest rates intent was to lead to higher credit availability to spur private domestic investments. There have been public-private partnership investments in the public sector especially in the provision of public infrastructure. Finally, successive governments have considered 1) stable interest rates, 2) high economic growth expectations, 3) political stability, 4) good doing business environment, and 5) regulations protecting business interests important to spur economic growth.

The nexus between internal investments and economic growth looks at the causality and significance between the two through direct and indirect channels (Javid, 2015) that has an impact on economic growth. To infer the nexus significance, this analysis entails looking at 1) cointegration tests, 2) significance regression coefficients, 3) the Granger causality, 4) variance decomposition of forecast error and 4) impulse response function that shows effect along with the steady level beyond the analysis period effect on economic growth. These results would profile the ranking and causality nature and significance impact of each investment type based on Kenya's economic growth, even though by default investments cause economic growth. As stated by Rabnawaz and Jaffar (2015), public investment affects economic growth differently in different countries, public and private investments could be substitutes or complementary, and crowding each other effects 
(Xu and Yan, 2014). On the other hand, financing and cost of public capital and private capital Klein (1997), consideration of gearing ratio (Sirtaine et al., 2005), and the level of buy-back of public-private partnerships investment optimal consideration cost on social time preference rate and the social opportunity cost of capital. It's from these arguments that this study intends to consider based on macroeconomic environment intervention for policy intervention.

However, beyond the above, policymakers require information on internal investment propensity and strength to respond to the incremental capital-output ratio required for economic growth. This study basis is to interrogate the linkages between units of internal investment on economic growth from a perspective that they depend on different instruments of the interest rate for discounting. The instruments for discounting being social discount rates, commercial lending rates, and hurdle rates of interest rates for the public, private domestic interest rates, and public-private partnership investments respectively. The findings of this study could be of help to policymakers to direct policies that would identify projects whose relationship behavior between internal investments and economic growth has positive externalities both in the short run and in the long-run process. To researchers on the significance of the study, factors, and determinants that affect the nexus between internal investments and economic growth could be an area of interest. Researchers could too consider foreign direct investments that are not part of this study nexus between internal investments and economic growth.

\subsection{Scope of the Study}

The objective of the study is to determine the nexus between internal investments and economic growth in Kenya using time series data between the years 1996 and 2017. The internal investment as the explanatory variable classification is 1) public investment, 2) private domestic investment and 3) public-private partnership investment while the dependent variable is real GDP for economic growth. The social-cost benefit analysis uses a social discount rate as a risk-free interest rate such as the short-term treasury bonds returns for public investments in discounting net present value. The commercial banking lending interest rates used in net present value by domestic investments have the risk premium factor. Finally, for publicprivate partnerships investment consideration of the above two to incorporate hurdle rates for a specific class of public risky projects by using the capital assets pricing model and Beta of the country risk premium. Treasury bonds yield, commercial banks lending rates, and expected return rates computed for capital asset pricing model applied as exogenous variables due to their effects on public, private domestic, and public-private partnership investments respectively.

The hypothesis of the study is on the internal investments' nexus on economic growth from explanatory variables and real economic growth in the short run and the long run from shock effects. The study intends to use secondary time-series data between the years 1996 and 2017 from World Bank Data, Kenya National Bureau of Statistics, IMF Data, Central Bank of Kenya, and other online data banks like 
Knoema and Penn where they are available.

\subsection{Limitations of the study}

The research study used secondary data of real GDP, public investment, private domestic investment, and public-private partnership investment as the endogenous variables. The time-series data for public-private partnership investment was not available for some years required for the analysis. As such, the interpolation function provided by the econometric application software of Eviews sorted out the problem. Before this decision, it was after KNBS advised public-private partnership investment information is yet collated by them, leaving the application of what was available from the World Bank database. Then, real interest rates for several years were negative, and a similar case of public investment in the year 2009, the rebase year. While real interest rates were accountable at then, public investment was due to the rebasing of the Kenyan GDP; coming after using the deflation value from the computation of the other variables (private domestic investment and foreign investments) attributed to the capital formation to arrive at the public investment that resulted in the negative value.

It was a surprise finding of a very insignificant influence of real interest rates and commercial banks lending interest rates on some endogenous variables. Real interest rates have an insignificant impact on private domestic investment. The same insignificance at even on a higher scale was in commercial banks lending interest rates on public-private partnership investment. Under this circumstance, does it imply real interest rates apply to external balance and no effect internally? On the other hand, does it also mean, commercial banks lending interest rates do not play a significant role in developing public-private partnership investment. This is from comparing the influence of various discounting rates when used as exogenous variables to the endogenous variables.

While the findings of the study collaborated with empirical studies considered, that were mostly from outside Africa, there were no studies under these objectives for citation in Kenya. Bearing in mind that there is developing interest in public-private partnership investment in the public domain for economic growth in Kenya. Secondly, lack of data on public-private partnership investment was also collaborated by KNBS; such that available data had to go through confidence building to make it fairly reflect the intended objectives of the analysis. Nevertheless, favorable leading results came out of the findings.

\section{Literature review}

The literature review chapter focuses on the nexus between investment and economic growth based on investment decision theories and empirical studies. The chapter starts by reviewing theories that inform on internal investment for economic growth. Empirical studies focus on studies that show linkages between internal investments and economic growth. 


\subsection{Theoretical review}

Three theories for the study that inform the investment decisions for public investments, private domestic investments, and public-private partnership investments considered are as follows. Time preference theory of Interest Rates basis for social discount preference for investments today and benefits in the future for public investments. Loanable Funds theory basis for market demand and supply for loanable funds from prevailing interest rates needed for private domestic investments. Finally, Asset Pricing Theory for the attractiveness of Public-Private Partnership Investments.

\subsubsection{Time preference theory of Interest Rates}

The theory attributed to economist Irving Fisher in his "The Theory of Interest, as Determined By Impatience to Spend Income and Opportunity to Invest It" in the 1930's". Fisher described interest rate as the price of time, and "an index of community's preference for a dollar of present over a dollar of future income." In Fisher's time preference theory of interest rates, supporters purport importance to individuals on saving and investment as the premium and discount on their present actions to future benefits while investors use net present value for investment appraisals referred to by Fisherian as "productivity-of-waiting" (Hebener, 2011, p. 8). However, according to critics, the theory does not account for the influence of the banking systems and elements of risk and uncertainty expected in the future. "In economic project analysis, the rate at which future benefits and costs are discounted relative to current values often determines whether a project passes the benefit-cost test" (Arrow et al., 2013). According to Arrow et al. (2013), discounting future benefits consider two rationales of consumption and investment. Consumption rate discount reflecting what society wills to trade consumption in the future for consumption today. While investment is attractive so long as the rate of investment return is positive then investing becomes admissible for the benefits in the future. The time preference theory of interest rates reflects premium on present and discount on future for all actions. Related to investments, neoclassical theory of investment, income is a function of employment given the capital stock, and its growth is determined in the capital market by the interest rate that equates the demand for investment and supply of the savings. However, due to market imperfections, interest rates may not raise investments to full employment levels in the short-run but eventually realizes the goal in the end. The investment and the output over time suggest numerous direct and indirect transmission channels needed to impact on economic growth in the future (Javid, 2015).

Since societies' relative valuation of current well-being versus future's well-being is time preference-based (Zhuang, Liang, Lin and Guzaman, 2007), social discount rates should be set according to this preference, especially in public investments. Where in public investments if social discount rates are set too high, then this could preclude socially desirable public projects; while if social discounts are set too low again this would risk having economically inefficient investments undesirable for 
economic growth impact. On the other hand, it is whether linkages between public and private investment are substitutes or complementary in the process for economic growth (Xu and Yan, 2014) since they compete for available loanable funds.

\subsubsection{Loanable Funds Theory}

The neo-classical theory of interest or loanable funds theory of interest owes its origin in the year 1898 to the Swedish economist Knut Wicksell. The loanable funds' theory state interest rates determination is by supply and demand for funds. Storm (2017) (as cited Mankiw (1997, p. 63)) illustrated the relationship between savings and investment as follows,

"In fact, saving and investment can be interpreted in terms of supply and demand. In this case, the "good" is loanable funds, and its "price" is the interest rate. Saving is the supply of loans - individuals lend their savings to investors, or they deposit their saving in a bank that makes the loan for them. Investment is the demand for loanable funds - investors borrow from the public directly by selling bonds or indirectly by borrowing from banks. [....] At the equilibrium interest rate, saving equals investment and the supply of loans equals the demand" (Mankiw, 2017, p. $63)$.

This view referred to as "the savings finances investment" doctrine on loan funds theory proponents implies that in abstaining in consumption is a necessity for more credit availability for investors (Lindner,2013) (as cited Robertson, 1936; Ohlin,1937, Tsiang,1956). However, lenders who are commercial banks could extend their balance sheet by increasing financial assets by creating new loans and increasing liabilities from new deposits thus no need for abstaining in consumption. This is such that if demand for borrowing increases, this will push up the cost of borrowing and vice versa. The relationship between the domestic rate of interest and the actual volume of domestic investment in a period for an economy depends on the condition of equilibrium in the market for capital goods. Private domestic investment as an internal investment forms part of Aggregate Demand (SRAD) that influences the level of capital stock and productive capacity of an economy (longrun aggregate supply (LRAS)). Where demand for capital goods may arise from induced investments due to a change in income or consumption. A reflection in the IS-LM model provides equilibrium in the goods market and money market. Macroeconomic expansionary policies affect the equilibrium level of prevailing interest rates and income. The change in income changes consumption patterns, which result in a demand for more goods and services. This further leads to induced demand for more domestic investment growth needs towards new potential GDP. The attraction of more investments continues until the marginal efficiency of capital in the market is equal to market lending rates of interest. The resultant effect of increased private domestic investment is increasing gross capital stock and lowering the capital-output ratio for the desired actual growth rate in output for warranted GDP growth rate. As such, loanable funds theory strengthens the fact that 
conventional factors of real interest rates, private sector credit availability, and past economic growth influence the behavior of investments according to Ames et al. (n.d.).

Government domestic borrowing to finance public expenditure affects loanable funds available for private domestic investments (Lidiema, 2017). On the other hand, a decline from private domestic investments in Kenya from 1.3 points to 0.3 points of GDP was due to government fiscal expansion (World Bank report (2018)). However, the role of private domestic investments in a country tends to be specific to each country. USA's economic growth significantly depends more on private domestic investments while in Japan it is public investments (Zou, 2016).

\subsubsection{Asset Pricing Theory}

The asset pricing theory is a theory behind the pricing of capital assets that takes into account the risk and return of investments. Jack Treynor, William Sharpe John Litner, and Jan Mossin introduced CAPM by building on earlier works by Harry Markowitz. CAPM's general idea is one such that investors need compensation in two ways of the time value of money and risk (Sharpe, 1964). It enables the evaluation of the private sector required return on investments from the associated level of risk in similar projects. According to Zucchi (2019), CAPM employs a simple calculation method to compute expected returns and eliminates specific unsystematic risk. However, the risk-free yield of short-term government securities tends to be prone to volatility, and project beta is difficult to determine that may affect outcome reliability. Public-private partnership investments involve investment decisions that jointly require social discount rates as risk-free, project market risks, and uncertainty (country project risk) discounting due to the nature of public investments when private investors are involved. However, both are bound to benefit if they jointly engage in the venture from a win-win situational agreement (Schachter, Daniel and Liu, 2017). For a government to achieve a return on investment, return on investment discounting from the private sector needs to be commensurate with the level of associated risk. This is the reason the Australian government decided to adopt the CAPM methodology for evaluating PPPs proposals through a circular referenced Finance Circular No. 2009/02 (2009). The reasons being to align with the country's own National PPPs Policy and Guidelines based on transparent differentiation between low and high-risk procurement options and risk assessment.

\subsection{Conceptual Framework}

The conceptual framework is a presentation of the nexus between internal investments and economic growth arguments based on the relationships that exist between the dependent and independent variables. Public investment decisions as influenced by social discount rates as risk-free interest rates. This looks at the social discount rate as Fisher's time preference interest rate as that of the short-term bond's rate of treasury bills that the government floats to raise investment funds. Private 
domestic investment depends on commercial banks lending interest rates value whose influence is from the availability of loanable funds. Public-private partnership investment that considers risks and uncertainties, therefore, incorporating asset pricing theory (CAPM) risk premium. The expected returns, therefore, depending on risk-free interest rates, market interest rates, and Beta coefficient computation on public projects risk inherent in public investments.

If there were no interest rate spread in discounting used in returns on investments by internal investments, then there would be no differential linkages between internal investments and economic growth. At the same time, the nexus between internal investments, means social discount rates, prevailing nominal interest rates, and expected returns based on risks implies intersection of crowding out/in effects and causality from available loanable funds available for these investments on economic growth would be non-existence.

Therefore, the conceptual framework tries to demonstrate the nexus between internal investments and economic growth by addressing the linkages to what the effects are on unit increases from public investment, private domestic investment, and public-private partnership investment with exogenous variables under social discount rates, commercial lending rates, and hurdle interest rates.

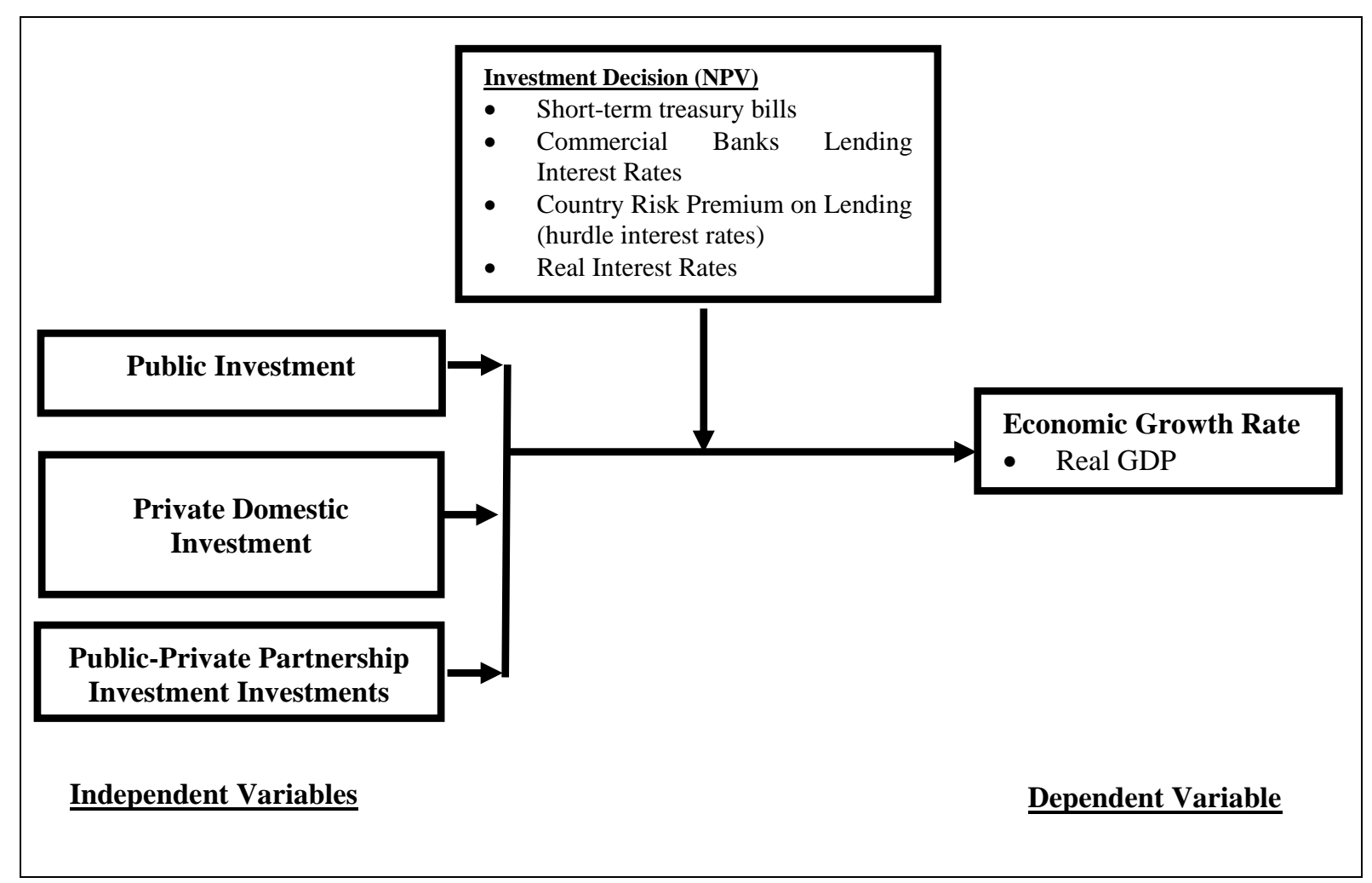

Figure 1: Conceptual Framework 
Therefore, the study target for analysis is how the independent variables (public investment, private domestic investment, and public-private partnership investment) links with economic growth. The independent variables are moderated by investment decisions from static exogenous instruments set outside the scope of this study. These instruments are short-term treasury bills rate as a proxy to the social discount rate, commercial banks lending interest rates, the country risk premium on lending, and the real interest rates. The theories behind these independent variables relate to the time preference theory of interest rates for public investments as the premium that discounts on present actions to future benefits (Hebener, 2011, p. 8; Zhuang, Liang, Lin \& Guzaman, 2007). Loanable funds theory on private domestic investment basing on commercial banks lending interest rates that relate to demand of investments and supply for funds (Storm, 2017). Asset pricing theory considers the time value of money and risk (Sharpe, 1964) that affects the attraction of publicprivate partnership investment return to private investors vis-vis on public interest.

\subsection{Empirical Literature Review}

Countries with a high investment/GDP ratio boost the country's competitiveness, employment, and reduces social and income disparities that lead to higher economic growth (UNCTAD, 2010; Anwar \& Sampath, 1999). Induced investment requires to meet the increased demand for goods and services. Induced investment demand is from income or consumption changes that productive capacity from internal investments need to respond to. Public investments, private domestic investments and now becoming important public-private partnership investments in a country play an important role to meet the production capacity required to meet the increased demand for goods and services or else inflationary tendency may set in. If increased investment meets the demand for goods and services, then this reduces the capital-output ratio from increased gross capital stock required for economic growth. However, causation and crowding effects amongst the independent variables and the dependent variable are amongst the nexus for consideration. This section looks at some relevant empirical studies that inform internal investments link to economic growth.

\subsubsection{Public Investments}

The government of Bangladesh over time raised its public investment to about $6.90 \%$ of the public investment-GDP ratio. Over the same time, private investment remained stagnant making Saidjada \& Jahan (2018) examine the relationship between public and private investment from a notion there could have been a crowding effect. Using data between 1981 and 2015, the variables considered were a real private investment, real public investment, real GDP, and real interest rate. To estimate the relationship between public investments, private investments, and economic growth, they used an autoregressive-distributed lag bounds testing framework. The findings suggested public investment negatively affected private investment. This implied long-run and short-run existence of crowding-out effects. 
Secondly, private investments had a low sensitivity to interest changes.

Zou (2006) examined using empirical studies interaction between public and private investment and GDP growth for Japan and the USA. The data for the two countries according to Zou had features that were so different requiring a different application of empirical methods for analysis. For this reason, prompting the use of OLS (Ordinary Least Squares) and GMM (Generalized Method of Moments) for the USA and Japan analysis methods in that order. Empirical results for Japan suggested that both public and private investments made great contributions to economic growth. While for the USA, the private investment seemed to play a greater and a more significant role compared to public investment.

$\mathrm{Xu}$ and Yan (2014) examined whether government investment "crowds out" or "crowds in" private investment in China. Xu and Yan divided government capital expenditure into two types; (1) investment that serves to provide public goods and infrastructure and; (2) investment in private industry and commerce. Since 1997, the Chinese government began implementing an ambitious expansionary fiscal policy (13\% of GDP, $\$ 576$ Billion, 23\% of total national investment) and the issue for examination was whether there was between public and private investment any substitution or complementarity between them that could affect economic growth. In other words, whether directly or indirectly there was crowding out or crowding in private investment that could affect economic growth negatively. Xu and Yan used a structured vector auto-regressive analysis method and the results suggested that government investment in public goods in China significantly "crowds in" private investment while government investment in private goods, industry, and commerce mainly through state-owned enterprises, "crowded out" private investments significantly.

Ghani and Din (2006) investigated the role of public investment in the process of economic growth in the context of Pakistan's economy, using the vector autoregressive (VAR) approach. Basing their study on theoretical considerations, the model included private investment and public consumption besides public investment. The results of the study showed economic growth driven by private investment had no strong inference from the effects of public investment and public consumption on economic growth. According to Ghani and Din, public investment had a negative impact with an insignificant impact on output, raising concern over the efficiency of public investments.

Rabnawaz and Jafar (2015) in another study for Pakistan, they examined the relationship between GDP and public investment using time series data for the period 1980-2009. The data came from the Pakistan Bureau of Statistics, State Bank of Pakistan (SBP), and Stockholm International Peace Research Institute (SIPRI). Empirical results showed there was a positive relationship between GDP and public investment in the short run. According to Rabnawaz and Jafar, the increase in GDP caused a rapid increase in public investment. Granger causality test showed bicausal relationship existence between GDP and public investment meaning causality ran from GDP to public investment and similarly from public investment to GDP. 


\subsubsection{Private Domestic Investments}

Lidiema (2017) in Kenya analyzed government domestic borrowing effects on private investment. In this study, the fixed capital gross formation was the dependent variable while the domestic lending rate, domestic debt, external debt, and financial development were the independent variables. The study used cointegration tests for the long run and short-run relationship between the dependent and independent variables. Using the Auto-Regressive Distributed Lag (ARDL) model, Lidiema found domestic debt had a negative and significant relationship with gross fixed capital formation. However, according to Lidiema, the relationship between domestic debt and fixed capital formation seemed to diminish in the long run.

Makuyana and Odhiambo (2018) examined the contribution of public and private investment to economic growth in Malawi between the years 1970 and 2014. They also considered the crowding effects of public investment and private investment. Earlier studies had used cross-sectional data in nature (Makuyana and Odhiambo, 2018). In their case for analysis, they analyzed for differential impacts of public and private investments on economic growth. The procedure for analysis applied was autoregressive distributed lag model (ARDL) bounds testing. Results showed private investment contributed more to economic growth than public investment. Also, infrastructural public investment had a crowding-in effect on private investments for economic growth.

In Malaysia, Bakari (2017) investigated the relationship between domestic investment and economic growth in the long-term and short-term. He conducted correlation analysis and co-integration tests. From these results, he estimated the relationship using the VECM model and checked for the Granger Causality. According to results, the analysis showed a positive impact of domestic investment, exports, and labor on economic growth in the long term even though there was no relationship between domestic investment and economic growth in the short term. The findings showed domestic investment, exports, and labor as a source of economic growth in Malaysia from which Bakari asserted as attributed to excellent infrastructure in Malaysia.

Olweny and Chiluwe (2012) examined the relationship between monetary policy and private sector investment in Kenya; by tracing the effects through the transmission mechanism; to explain how investment responded to changes from monetary shocks. Domestic debt, gross domestic savings, money supply, and interest rates were the variables used to find the effect on private domestic sector investments. Quarterly macroeconomic data from 1996 to 2009 tested for unit root tests (stationarity); cointegration tests and vector error correction model (VECM) to explore the dynamic relationship of short-run and long-run effects due to exogenous shocks. The variables were stationary from the first difference, then using ordinary least squares estimated the long-run relationship that showed a negative relationship between domestic debt and treasury bills; while positive relationship to domestic saving and money supply which all collaborate internal 
balance principles of the IS-LM model.

Emmanuel and Kehinde (2018) investigated in Nigeria the impact of sluggish growth of domestic investments on economic growth. To determine the long-run relationship between sluggish domestic investment growth and economic growth, they applied co-integration tests and Granger causality tests to determine the relationship. The results showed a long run significant relationship exists between GDP growth and domestic investment. The study also found that domestic investment positively influenced real gross domestic product. To create domestic investment opportunities for capital formation, Emmanuel and Kehinde (2018) from these results recommended the government of Nigeria adopts macroeconomic policies and a favorable enabling environment to boost investment opportunities to contribute to economic growth.

\subsubsection{Public-Private Partnerships Investment}

Using a VAR model in Portugal, Pimentel, St.Aubyn, and Ribeiro (2016) tested for the macroeconomic impact of investing in a public-private partnership, public investment, and private investment; whereas independent variables were public investment, private investment, PPPs. The GDP as the dependent variable, over the period between 1998 and 2013, Pimentel et al. (2016) they assessed crowding-in and crowding-out effects. Pimentel et al. (2016) also proceeded to calculate macroeconomic rates of return on investment in PPPs, public investment, and private domestic investment. The results showed that public and private investment had a positive effect on GDP but investment in PPPs reduced the Portuguese GDP. From the same results, they found PPPs' investment still crowded out both private and public investment. While public investment had a crowding-in effect on both private investment and PPPs investment and still, private investment showed the same crowding-in effect on both investment in PPPs and public investment.

Jasiukevicius and Vasiliauskaite (2013) using time-series data for 20 years; examined the relationship between economic growth and public-private partnership investment market development for EU countries. To get the relationship between the two, they used scientific literature, statistical data analysis, and document analysis. The findings were that GDP growth influenced positively market development for public-private partnerships in the countries. In some countries like Belgium, Ireland, France, and the United Kingdom (UK) there was a strong correlation between GDP growth and public-private partnership market development; however, in most of the other countries, there was no statistically significant difference between the impacts of GDP growth on the PPPs market development. Nevertheless, in their conclusion cautioned against the low correlation between GDP growth and public-private partnership investments market development in the other countries as the fact.

The objective of the paper was to examine the relationship between the scale and nature of PPPs' contribution as a driver of economic growth. According to Zangoueinezhad and Azar (2014), the purpose of public-private partnerships (PPPs) 
was a mutual benefit for the relationship between the public and private sectors. The private-sector partner typically makes a substantial equity investment while the public sector gains access to new or improved services in return. Zangoueinezhad and Azar asserted that when structured well with careful and critical examination, PPPs allocate risk to the party best suited to handle it. The study used statistics causality modeling based on relevant statistical techniques, dynamic interactions, and interdependencies over PPPs all that addressed and quantified economic growth. The findings were, though PPPs release government resources to alternative public priorities; three important enabling factors for success were that 1) PPPs stimulate a country's economic growth based on the number of PPPs projects in progress, 2) PPPs projects value, and 3) the ideal type of PPPs contracts applied. The number, value, and type of PPPs, combined with supportive policies would power economic growth. Adding that governments with well-established and enforced policies against corruption, combined with low business transaction costs, a transparent legislative system, and exchange rate and monetary stability status; were far more attractive to the private sector for PPPs engagement required for economic growth according to to Zangoueinezhad and Azar (2014).

Sarmento and Oliveira (2018) explored the use of the Capital Asset Pricing Model (CAPM), which has become standard and popular in corporate finance for assessing the risk and return in shareholders' equity in some transportation projects in Portugal. They found in highly leveraged projects; the method could result in misleading discounting values. This was from a sample of 20 highway projects despite Portugal being the greatest user of Public-private partnership investments in Europe. As such, according to their findings, they showed that the values that the CAPM provided for projects applying debt to finance, over $80 \%$ of total investment were unrealistic due to the high leverage value in the CAPM formula. In their conclusion, it is such that with larger and more complex investment projects, perceived higher risk results in demand for higher risk premiums in such projects. Song, Zhao, Jin, and Sun (Nov. 2018) stated that government guarantees frequented in the application by public-private partnership (PPPs) toll road projects to attract private sector partners. Song et al. (2018) paper objective was to bring out the importance of coordination of interests of the government and that of the private firm and determining government guarantee that would be optimal. Under two typical government guarantees, Song et al. applied a multi-objective programming model to determine the Pareto-optimal toll, demand quantity, monopoly power, private firm's profits, and social welfare. Under certain assumptions, they found that for any government guarantee, the Pareto-optimal toll lay between the toll set by private firms and the socially optimal toll; also, the Pareto-optimal toll tended to be higher where monopoly power was stronger under minimum demand guarantee if the relative negotiating power of private firms was sufficiently high. This meant that both the private firm's profit and social welfare depended on relative negotiating power, buyback price, marginal social cost, and minimum quantity demanded. Song et al. therefore found that if the minimum quantity demanded and the buyback prices are sufficiently high, the government would tend to provide an exclusivity guarantee 
but not a minimum demand guarantee to private firms as a policy implication. Successful guarantee from optimization in Kaldor-Hicks efficiency would always lead to more investments under PPPs benefits through capital-output ratio (efficiency) for gross fixed capital accumulation required for economic growth.

\subsection{Critique of the Existing Literature Relevance to the Study}

Five empirical studies under public investments provided valuable information with interest rates from social discount rates that did not come out explicitly in the studies. Saidjada \& Jahan (2018) for the case of Bangladesh based their study on public investments continued to show an increase in contribution to GDP by growth while domestic investments were stagnant. The findings to the effect there was a crowding effect confirmed the stagnation proposition. Xu and Yan (2014) considered the crowding effects of public investments in China. Ghani and Din (2006) considered the role of public investment in the process of economic growth in Pakistan and Rabnawaz and Jafar's (2015) relationship between GDP and public investment in Pakistan. In these studies, all agree that public investments lead to economic growth except that $\mathrm{Xu}$ and Yan focused more on crowding out effects with Ghani and Din disagreeing that public investments had a significant contribution to Pakistan's economic growth at the time of study during the short-run. Ghani and Din in some ways disagree with Rabnawaz and Jafar coming after 10 years that public investment had different effects on economic growth in the same country in the short-run. Xu and Yan's findings were specific that public investments in public goods and services crowds in private investments but when public investments through state corporations investing in private goods, industry, and commerce crowd out private investments which makes relevance for further consideration on specific internal investments. Under this circumstance, we have cases as examples in Kenya like in SGR and private transporters, state corporations like in the Sugar industry might have crowding effects where the level of effects on capital-output ratio may need ascertainment. Finally, Zou (2006), comparing public investments and private investments, Japan and the USA have different significant contributions to economic growth where both investment types have the same contribution to economic growth in Japan while the USA its private sector that is more dominant. There are five studies considered on private domestic investments that influence economic growth with one taking monetary policy effects. Lidiema (2017) study in Kenya addressed government borrowing and domestic investment relationship to gross capital formation. Likewise, Makuyana and Odhiambo (2018) looked at public investments and private domestic investment crowding effects in Malawi. The study in Malaysia by Bakari (2017) gave findings on the effect of domestic investments, labor, and export's impact on economic growth. In Kenya, Olweny and Chiluwe (2012) considered domestic investment effects from monetary policy. They used aspects of domestic debt, gross domestic savings, money supply, and interest rates impact on domestic investments leading to economic growth. Emmanuel and Kahinde (2018) investigated the effects of stagnated growth of 
private domestic investments in Nigeria on economic growth. Short-run and longrun dependencies on economic growth from private domestic investments were part of the findings in all the three studies that form the dynamic framework for the need for capital-output ratio attainment for economic growth through the marginal efficiency of investments. Effects of loanable funds availability to domestic investment dependence and public investment dependence on government borrowing from the relationship of lending interest rates and bonds yield inverse relationship provides a nexus.

The five studies considered on PPPs were by Song at el. (Nov. 2018), Pimentel at el. Ribeiro (2016), Sarmento and Oliveira (2018), and Zangoueinezhad and Azar (2014). For a public-private partnership to offer required economic growth through investments scenarios: 1,) government guarantee consideration for successful PPPs; 2) case impact of PPPs in Portugal on crowding effects; and 3) how PPPs could contribute significantly to economic growth and 4) Capital Asset Pricing Model (CAPM) assessment of risk and return in shareholders' equity on Portugal. Public investments and private investments from previous studies show that they contribute to economic growth through capital-output ratio and public investments even though they could crowd out or crowd in private investments. Song at el. (2018) considered public social benefits and private benefits optimality; and buyback of the project as important when drawing PPPS contracts, negotiating guarantee to successful implementation. Another aspect considered is the crowding effects by Pimentel at el. and the number, size, value, type of PPPs, combined with supportive policies by Zangoueinezhad and Azar (2014)); that are important for economic growth's effectiveness from capital-output ratio influence from this type of projects.

\subsection{Summary and Research Knowledge Gaps}

Investments are beneficial to a country as they lower capital output-ratio required in raising productivity as a country responds to increased demand for goods and services thus raising the standards of living. Public investment as a driver for investments enables according to time preference theory of interest rates and marginal neoclassical theory of investments to consider social discount rate in the plan of how much to invest for the future generations as the social opportunity cost of capital. Return on investment and economic growth expectations in a country remains a decisive factor in determining the marginal efficiency of capital and availability of credit for investment (country capacity). As such, commercial lending rates and the marginal efficiency of investment capacity determine the level of investment. With the need for more merited public goods and services and budgetary constraints, insurance of private sector hurdle rates needs to be in line with associated risks. Thus, the private sector does not exploit public commitments therefore having a considerable reason for the government to ensure asset pricing for projects discounting is within its value for money and benefits into the future. Nevertheless, public-private partnership success delivers a solution for growing debt-GDP ratio, budget deficit, and efficiency in the delivery of such projects that 
it is quite important to the government for economic growth. However, it is scaling, value, optimizing private to public benefits, contracts nature, and corruption problems that come into the fore. These determine two-fold considerations on riskfree interest rates, market risk interest rates, and hurdle rates on one side, while the other side looks at how causality and crowding effects inter-relate to foster desired economic growth through capital formation by internal investments.

From the reviewed literature, the nexus between internal investments and economic growth significantly influence economic growth in the long run and the short-run. However, there are divergent findings especially on crowding effects and the time significant influence on economic growth. Table 1 provides a summary of literature reviewed and the corresponding objectives, research hypothesis and study authors (year and country), methodology, and findings reviewed.

Table 1: A summary of Empirical Literature Reviewed

\begin{tabular}{|c|c|c|c|}
\hline & Author/Date/Country & Methodology & Findings \\
\hline $\mathbf{A}$ & \multicolumn{3}{|c|}{$\begin{array}{l}\text { General Objective: } \\
\text { The study aims to determine the nexus between internal investments and economic growth from } \\
\text { investments by the public, private domestic, and public-private partnerships in Kenya between the } \\
\text { years } 1996 \text { and } 2017 \text {. }\end{array}$} \\
\hline B & \multicolumn{3}{|c|}{$\begin{array}{l}\text { Specific Objective: To determine the nexus between public investment and economic growth in } \\
\text { Kenya } \\
\text { Research Hypothesis: Ho1: Public investment has no relationship with economic growth in } \\
\text { Kenya. } \\
\text { Theoretical Model: Time preference theory of interest rates. }\end{array}$} \\
\hline 1. & $\begin{array}{l}\text { Saidjada \& Jahan } \\
\text { (2018, Bangladesh) }\end{array}$ & $\begin{array}{l}\text { Autoregressive- } \\
\text { distributed lag bound } \\
\text { testing }\end{array}$ & $\begin{array}{l}\text { Public investment negatively affected private } \\
\text { investment both in the long run and short run } \\
\text { meaning crowding-out effects' existence. }\end{array}$ \\
\hline 2. & Zou (2006) & $\begin{array}{l}\text { OLS (Ordinary Least } \\
\text { Squares) and GMM } \\
\text { (Generalized Method of } \\
\text { Moments) }\end{array}$ & $\begin{array}{l}\text { Both public and private investments made } \\
\text { great contributions to economic growth in } \\
\text { Japan. For the USA, private investment } \\
\text { played a greater and more significant role } \\
\text { compared to public investment. }\end{array}$ \\
\hline 3. & $\begin{array}{l}\text { Xu, X., \& Yan, Y. } \\
\text { (2014, China) }\end{array}$ & $\begin{array}{l}\text { Vector Autoregressive } \\
\text { analysis }\end{array}$ & $\begin{array}{l}\text { Government investment in public goods and } \\
\text { services significantly crowds in private } \\
\text { investments while if an investment is in } \\
\text { private, industry, and commerce through } \\
\text { state enterprises crowds out private } \\
\text { investments significantly. }\end{array}$ \\
\hline 4. & $\begin{array}{l}\text { Ghani, E., \& Din, M. } \\
\text { (2006, Pakistan) }\end{array}$ & $\begin{array}{l}\text { Vector Autoregressive } \\
\text { analysis }\end{array}$ & $\begin{array}{l}\text { Private investment drove economic growth } \\
\text { while public investments and consumption } \\
\text { were insignificant in the short-run. }\end{array}$ \\
\hline 5. & $\begin{array}{l}\text { Rabnawaz, A., \& } \\
\text { Jafar, R.M.S. } \\
\text { (2015, Pakistan) }\end{array}$ & $\begin{array}{l}\text { Time series analysis and } \\
\text { Granger Causality }\end{array}$ & $\begin{array}{l}\text { There was a positive significant relationship } \\
\text { between GDP and public investment in a bi- } \\
\text { directional way in the short run. }\end{array}$ \\
\hline
\end{tabular}




\begin{tabular}{|c|c|c|c|}
\hline $\mathbf{C}$ & \multicolumn{3}{|c|}{$\begin{array}{l}\text { Specific Objective: To establish the nexus between private domestic investment and economic } \\
\text { growth in Kenya. } \\
\text { Research Hypothesis: Ho2: Private Domestic investment has no relationship with economic } \\
\text { growth in Kenya } \\
\text { Theoretical Model: Loanable funds theory. }\end{array}$} \\
\hline 1. & $\begin{array}{l}\text { Lidiema } \\
\text { (2017, Kenya) }\end{array}$ & $\begin{array}{l}\text { Auto-Regressive } \\
\text { Distributed Lag (ARDL) } \\
\text { model }\end{array}$ & $\begin{array}{l}\text { Domestic debt to finance public investment } \\
\text { affected private investment (crowding effect) } \\
\text { leading to a negative and significant } \\
\text { relationship with gross fixed capital } \\
\text { formation. However, the relationship } \\
\text { between domestic debt and fixed capital } \\
\text { formation seems to diminish in the long run. }\end{array}$ \\
\hline 2. & $\begin{array}{l}\text { Makuyana and } \\
\text { Odhiambo } \\
(2018, \text { Malawi) }\end{array}$ & $\begin{array}{l}\text { Autoregressive } \\
\text { Distributed Lag Model } \\
\text { (ARDL) bounds testing. }\end{array}$ & $\begin{array}{l}\text { Private domestic investment contributed } \\
\text { more to economic growth than public } \\
\text { investment. Also, infrastructural public } \\
\text { investment had a crowding-in effect on } \\
\text { private investments for economic growth. }\end{array}$ \\
\hline 3. & $\begin{array}{l}\text { Bakari, S. } \\
\text { (2017, Malaysia) }\end{array}$ & $\begin{array}{l}\text { Correlation analysis, co- } \\
\text { integration tests, Vector } \\
\text { Error Correction } \\
\text { Method, Granger } \\
\text { causality }\end{array}$ & $\begin{array}{l}\text { A positive significant impact of domestic } \\
\text { investments, exports, and labor on economic } \\
\text { growth in the long-term though there was no } \\
\text { relationship in the short term between } \\
\text { domestic investment and economic growth. }\end{array}$ \\
\hline 4. & $\begin{array}{l}\text { Olweny, T., \& } \\
\text { Chiluwe,M. } \\
\text { (2012, Kenya) }\end{array}$ & $\begin{array}{l}\text { Unit roots tests, co- } \\
\text { integration, Vector Error } \\
\text { Correction Method }\end{array}$ & $\begin{array}{l}\text { The study was on the relationship between } \\
\text { monetary policy and private sector } \\
\text { investment. The finding was that domestic } \\
\text { debt, gross domestic savings, money supply, } \\
\text { and interest rates had dynamic relationship } \\
\text { effects in the short-term and long-term on } \\
\text { economic growth. }\end{array}$ \\
\hline 5. & $\begin{array}{l}\text { Emmanuel, O.E., \& } \\
\text { Kehinde, A. (2018) }\end{array}$ & $\begin{array}{l}\text { Co-integration, Granger } \\
\text { causality }\end{array}$ & $\begin{array}{l}\text { Found a long-term significant relationship } \\
\text { exists between GDP growth and domestic } \\
\text { investment. }\end{array}$ \\
\hline D & $\begin{array}{l}\text { Specific Objective: } \\
\text { economic growth in } \\
\text { Research Hypothe } \\
\text { economic growth in } \\
\text { Theoretical Model: }\end{array}$ & $\begin{array}{l}\text { o assess the nexus betwe } \\
\text { nya. } \\
\text { Ho3: Public-Private Pat } \\
\text { nya. } \\
\text { apital Asset Pricing Theory }\end{array}$ & $\begin{array}{l}\text { public-private partnership investment and } \\
\text { ership investment has no relationship with }\end{array}$ \\
\hline 1. & $\begin{array}{l}\text { Pimentel, I., } \\
\text { St.Aubyn, M., \& } \\
\text { Ribeiro, N. } \\
\text { (2016, Portugal) }\end{array}$ & $\begin{array}{l}\text { Vector AutoRegression } \\
\text { (VAR) }\end{array}$ & $\begin{array}{l}\text { PPPs investment crowded out both private } \\
\text { and public investment while public } \\
\text { investment had a crowding-in effect of both } \\
\text { private investment and PPPs investment and } \\
\text { still private investment showed the same } \\
\text { crowding-in effect on both investment in } \\
\text { PPPs and public investment. }\end{array}$ \\
\hline
\end{tabular}




\begin{tabular}{|l|l|l|l|}
\hline 2. & $\begin{array}{l}\text { Zangoueinezhad, A., } \\
\text { \& Azar, A. } \\
\text { (2014, Iran) }\end{array}$ & $\begin{array}{l}\text { Statistics causality } \\
\text { modeling (Granger } \\
\text { causality) }\end{array}$ & $\begin{array}{l}\text { Even though PPPs can free up government } \\
\text { resources for other public priorities, three } \\
\text { key enabling factors on PPPs to stimulate a } \\
\text { country's economic growth were the number } \\
\text { of PPPs projects underway, the value of PPPs } \\
\text { projects, and the ideal type of PPPs contracts } \\
\text { put in place. }\end{array}$ \\
\hline 3. & $\begin{array}{l}\text { Sarmento and } \\
\text { Oliveira } \\
\text { (2018, Portugal) }\end{array}$ & $\begin{array}{l}\text { Showed that the values that the CAPM } \\
\text { provided for projects applying debt to } \\
\text { finance over 80\% of total investment were } \\
\text { unrealistic due to high leverage values in the } \\
\text { CAPM formula. }\end{array}$ \\
\hline 4. & $\begin{array}{l}\text { Jasiukevicius and } \\
\text { Vasiliauskaite } \\
\text { (2013, European } \\
\text { Union) }\end{array}$ & $\begin{array}{l}\text { Scientific literature } \\
\text { analysis, statistical data } \\
\text { analysis, and document } \\
\text { analysis. }\end{array}$ & $\begin{array}{l}\text { Economic growth and development of } \\
\text { public-private partnership market } \\
\text { development had significant relationships in } \\
\text { some EU countries and not significant in } \\
\text { others on economic growth. }\end{array}$ \\
\hline 5. & $\begin{array}{l}\text { Song, J., Zhao, Y., } \\
\text { Jin, L., \& Sun, Y. } \\
\text { (Nov. 2018, China) }\end{array}$ & $\begin{array}{l}\text { Multi-objective } \\
\text { programming }\end{array}$ & $\begin{array}{l}\text { For any government guarantee, the Pareto- } \\
\text { optimal toll lied in between the toll set by } \\
\text { private firms and the socially optimal toll; } \\
\text { also, the Pareto-optimal toll tended to be } \\
\text { higher and monopoly power was stronger } \\
\text { under minimum demand guarantee if the } \\
\text { relative negotiating power of private firms } \\
\text { was sufficiently higher than the government. }\end{array}$ \\
\hline
\end{tabular}

\section{The data and methodology}

This chapter presents the methodology and data used to carry out the study. In detail, the chapter considered the methods to collect secondary data required for the analysis of the nexus between internal investments and economic growth. The researcher discusses the research design and target population applied for this study. Finally, the last section discusses in detail the data collection procedure, collected data processing, and analysis used to arrive at the findings.

\subsection{Research design}

The study-adopted causality research which best suits the nexus between internal investments and economic growth. Since the observations were several time-series data on annual intervals between the years 1996 and 2017, the researcher preferred to adopt longitudinal research design. The motivation for the choice was on its ability to determine the effect and cause of endogenous and exogenous variables. The exogenous variables considered are real interest rates, risk-free interest rates, commercial lending rates, and the country risk premium on lending. According to Shrestha and Bhatta (2018), time-series data tend to have some sort of relationship between current values with its previous data. In which autoregressive (AR) character in time series data presents current value as determined by its past values 
with adjustment factors as in this study case.

\subsection{Target Population}

The time-series data was for real GDP growth, public investment, private domestic investment and public-private partnership investment, real interest rates, social discount rates (short-term bonds), commercial lending interest rates, and the risk premium on lending. The sources of the data came from the Kenya National Bureau of Statistics, Central Bank of Kenya, World Bank, International Monetary Fund, UNCTAD databases, and other relevant sources. The choice of this period (1996 to 2017) was due to the dynamic changes that occurred in Kenya and globally with direct and indirect implications on economic growth in Kenya. Country Strategy Paper (CSP) for Kenya prepared by the African Development bank for years 20082012 and 2014-2018 highlighted some of the dynamic changes in social, political, and economic approaches from the government to spur economic growth.

\subsection{Data collection procedure}

To achieve the objectives of the study, the data collection focused on endogenous and exogenous variables as given in these subsections.

\subsubsection{Endogenous Variables}

Real GDP - As the dependent variable, the real GDP variable is on actual values. The data came from the Central Bank of Kenya website, which was consistent with the World Bank's website. The time-series data was on an annual basis starting with the year 1996 to 2017. Public Investments: - As an explanatory variable, public investment, data is on actual values. The data was available from the Central Bank of Kenya website as government development expenditure. The time-series data for public investment was annualized for each year since it was available monthly from the year 1996 to 2017. Private domestic investment: - As an explanatory variable, private domestic investment is on actual values and domestic savings presented to cover as the proxy. The data was available in the Kenya National Bureau of Statistics as a percentage of GDP from the year 2006 to 2017 while earlier data came from the Word Bank data website. Public-Private Partnership investment: The variables employed actual values of investment on an annual basis for the period under study 1996 to 2017. The source of the World Bank data website had values for some years and the rest could not be available.

\subsubsection{Exogenous Variables}

The real interest rate is the exogenous variable for real GDP. The social discount rate is the exogenous variable attached to the public investment variable. As an exogenous variable, the social discount rate being equated to the treasury bills returns of Central Bank of Kenya rate provided in monthly percentages. This required annual average computation for the study's purpose. In the United States, economists use return on short-term bonds (90 days) as riskless interest rates 
(inflation risk is small over a short period) even though understates the riskless interest rates due to negative correlation with market returns especially during inflationary periods (Harrison, 2010, p. 117). Commercial Banks Lending Interest Rates is the exogenous variable attached to the private domestic investment variable. The commercial bank's lending interest rates monthly rates are available from the Central Bank of Kenya website for the period under study. For the analysis purposes, computation of the average rate for each year was inevitable. CAPM adjusted expected return discounting computation on public-private partnership investments was based on treasury bills return and commercial banking lending interest rates difference. Using CAPM expected returns $\left(E_{r}\right)=R_{f}+\beta\left(R_{m}-R_{f}\right)$ equation, where $\beta$ (Beta) computation is from volatility measure between treasury bills rates and commercial banks lending rates. Since consideration was based on internal investments in the country, market $\beta$ was considered as equal to one, therefore taking $R_{m}-R_{f}$ as equivalent to risk premium on commercial bank's lending rate.

\subsection{Data Processing and Analysis}

The research used the AutoRegression Distributed Lag (ARDL) to analyze the nexus between internal investments and economic growth. Since not all time-series variables were stationary at the same level. To shorten variable naming, the representation of the variables used the following keys for the study,

\section{Target Model Equation:}

1. X1 = Real GDP: coefficients as C1 (intercept), $\alpha 1, \alpha 2, \alpha 3$, $\alpha 4$, and $\mu 1$ (error term).

\section{Other Endogenous Equations:}

2. $\mathrm{X} 2$ = Public Investment: coefficients as $\mathrm{C} 2$ (intercept), $\beta 1, \beta 2, \beta 3, \beta 4$ and $\mu 2$ (error term).

3. $\mathrm{X} 3=$ Private Domestic Investment: C3 (intercept), $\varphi 1, \varphi 2, \varphi 3, \varphi 4$ and $\mu 3$ (error term).

4. X4 = Public-Private Partnership: C4 (intercept). $\tau 1, \tau 2, \tau 3$, $\tau 4$, and $\mu 4$ (error term).

\section{Note:}

The impact parameters to be estimated are Real GDP $(\alpha 1, \beta 1, \varphi 1, \tau 1)$; Public Investment $(\alpha 2, \beta 2, \varphi 2, \tau 2)$; Private Domestic Investment $(\alpha 4, \beta 4, \varphi 4, \tau 4)$, and Public-Private Partnership Investment $(\alpha 5, \beta 5, \varphi 5, \tau 5)$ influence across the ARDL system model as all being endogenous variables and $\gamma$ coefficient for the exogenous variables. While $\mathrm{C} 1, \mathrm{C} 2, \mathrm{C} 3$, and $\mathrm{C} 4$ are the constants or autonomous components.

\subsubsection{ARDL with Exogenous Variables Model Specification}

Autoregressive Distributed Lag and Vector Autoregression (VARX) model applications are common in the studies involving time-series data, such as in finance, economics, and business applications (Warsono et al., (2019). The models can explain dynamic relationship behaviors existence between endogenous and 
exogenous variables. VAR is also useful in determining the influence of a variable or set of variables on others by using impulse response function, prediction, and forecasting in time series. The period of years 1996 to 2017 inclusive came to 22 observations that is a small sample size. The ARDL method bounds testing considers I (0) and I (1) integration levels and is more accurate with a small sample size (Menegaki,2019; Akbota and Baek,2017; Lee, 2012; Pahlavani, Wilson, and Worthington, 2005) compared with other methods like Johanssen that requires a big sample size. In this study, the ARDL model was used for the analysis of a 4-variable vector model using Real GDP (X1), Public Investment (X2), Private Domestic Investment (X3), and Public-Private Partnership Investment (X4) with exogenous variables of real interest rates (E1), treasury bills rates (E2), commercial bank's lending interest rates (E3) rates and expected returns of risky investments (E4) using country risk premium on lending. Such that the generalized model for consideration ARDL $\mathrm{k}, \mathrm{m}(\mathrm{p}, \mathrm{s})$, has a stationary k-dimensional vector series [Yt] in terms of past $\mathrm{p}$ values and the past $\mathrm{s}$ values of a stationary m-dimensional vector series $[\mathrm{Xt}]$ represented as:

$\mathrm{Y}_{\mathbf{t}}=\mathrm{C}_{\mathrm{i}}+\sum_{l=1}^{p} \Phi_{\mathbf{l}} \mathrm{Y}_{\mathbf{t}-\mathbf{l}}+\sum_{j=1}^{s} \beta_{\mathbf{j}} \mathrm{X}_{\mathbf{t}-\mathbf{j}}+\varepsilon_{\mathbf{t}}$

Where $Y_{\mathbf{t}}$ are endogenous variables (real GDP, public investments, private domestic investments, and public domestic investments) and $\mathrm{X}_{\mathrm{t}}$ are exogenous variables (real interest rates, treasury bills rates, commercial lending rates, and hurdle rates) and $\varepsilon_{\mathbf{t}}$ error term. $\Phi$ and $\beta$ represent the coefficients of endogenous and exogenous variables respectively. The resulting equations for the ARDL model will be the raw time series data converted into natural log functions and expressed as follows,

$\underline{\operatorname{Real} \mathrm{GDP}\left(\mathrm{X}_{1 \mathrm{t}}\right)}$

$$
\begin{aligned}
& \log \underline{X_{1 t}}=C_{1}+\underline{\alpha_{1}} \log \left(X_{1 t-1}\right)+\alpha_{2} \log \left(X_{2 t-1}\right)+\alpha_{3} \log \left(X_{3 t-1}\right)+\alpha_{4} \log \left(X_{4 t-1}\right)+\gamma 1 \log \left(E_{2}\right) \\
& \gamma_{2} \log \left(E_{3}\right)+\gamma_{3} \log \left(E_{4}\right)+\mu_{1 t} .
\end{aligned}
$$

Public Investments $\left(\mathrm{X}_{2 \mathrm{t}}\right)$

$$
\begin{aligned}
& \left.\log \underline{X}_{2 t}=C_{2}+\beta_{1} \log \left(X_{1 t-1}\right)+\underline{\beta}_{2} \log \left(X_{2 t-1}\right)+\beta_{3} \log \left(X_{3 t-1}\right)+\beta_{4} \log X_{4 t-1}\right)+\gamma_{1} \log \left(E_{1}\right) \\
& \gamma_{2} \log \left(E_{3}\right)+\gamma_{3} \log \left(E_{4}\right)+\boldsymbol{\mu}_{2 t} .
\end{aligned}
$$

$\underline{\text { Private Domestic Investments }\left(\mathrm{X}_{\mathbf{3 t}}\right)}$

$\log \underline{X}_{3 t}=C_{3}+\varphi_{1} \log \left(X_{1 t-1}\right)+\varphi_{2} \log \left(X_{2 t-1}\right)+\varphi_{3} \underline{\log \left(X_{3 t-1}\right)}+\varphi_{4} \log \left(X_{4 t-1}\right)+$ $\gamma_{1} \log \left(E_{1}\right) \gamma_{2} \log \left(E_{2}\right)+\gamma_{3} \log \left(E_{4}\right)+\mu_{3 t}$.

\section{Public-Private Partnership Investments $\left(\mathrm{X}_{\mathbf{4 t}}\right)$}

$$
\begin{aligned}
& \log \underline{X}_{4 t}=C_{4}+\tau_{1} \log \left(X_{1 t-1}\right)+\tau_{2} \ln \left(X_{2 t-1}\right)+\tau_{3} \log \left(X_{3 t-1}\right)+\underline{\tau_{4} \log \left(X_{4 t-1}\right)}+\gamma_{1} \log \left(E_{1}\right) \\
& \gamma_{2} \log \left(E_{2}\right)+\gamma_{3} \log \left(E_{3}\right)+\mu_{4 t} .
\end{aligned}
$$




\subsubsection{Stationarity Tests (Unit Root Test).}

As a time-series data, the data required verification for stationarity by preliminary plotting graph (to check for trend) and then the Augmented Dickey-Fuller Test (Unit Root Test) to know the co-integration model to apply. Else, spurious results may prevail if non-stationary data or long specification if data is non-stationary data. The Augmented Dickey-Fuller Test was the preferred test for unit roots for stationarity tests. The hypothesis testing was based on a 5\% confidence level for the three test equations (intercept, trend, or intercept, and none conditions). Where the test basis is the Null Hypothesis of "Variable not stationary - has unit root(s)" and ALT Hypothesis "Variable stationary - has no unit roots". Another check at 5\% was the absolute value of t-statistic where it should be greater than the absolute critical value at the $5 \%$ confidence level.

\subsubsection{Optimal Lag structure}

In most economic time series data, a variable depends on another variable with a lapse of time (lag). The essence of optimal lags consideration was that if there are too many lags; this could lead to loss of degrees of freedom. Also, too many lags may cause multicollinearity, serial correlation in the error terms, and misspecification errors. Akaike Information criterion with the lowest value computed gives optimal lag best for use in the analysis model.

\subsubsection{Co-integration Tests}

After the stationary unit root test and optimal lag determination, the co-integration test of internal investment variables and real GDP was necessary to establish whether a long-run relationship exists among or between variables. Johansen cointegration test function tests for a long-run relationship, in mind, that the order for the target variable as important and optimal lag (Non-stationary, integrated of the same order, raw data). However, the ARDL co-integration bounds test was inevitable after public investment time-series data were co-integrated in I (0) and the others at I (1). The test hypothesis being H0: "No co-integration" and H1: "There was co-integration". The criteria for the co-integration test as such that if the p-value is greater than 5\% (bounds values for ARDL co-integration) there is a long-run relationship (reject the null hypothesis) i.e. co-integrated; otherwise no cointegration or there is no long-run relationship (accept null hypothesis). From this co-integration tests, then:

1. Variables are not co-integrated: This meant the only estimation of the short-run model of the Unrestricted VAR model.

2. Variables are co-integrated: Means estimation of both short-run and long-run models using ARDL and ECT models i.e. Restricted (co-integrated - VECM). 


\subsubsection{ARDL Estimation of the equation(s)}

The target ARDL model was either to be unrestricted if no co-integration or restricted if there was co-integration in the four endogenous variables. The target variable as real GDP from the nexus of internal investments (public investment, private domestic investment, and public-private partnership investment).

1. Unrestricted Model

$$
\mathrm{Yt}=\mathrm{C} 1+\alpha 1 \mathrm{X} 1 \mathrm{t}-1+\alpha 2 \mathrm{X} 2 \mathrm{t}-1+\alpha 3 \mathrm{X} 3 \mathrm{t}-1+\alpha 4 \mathrm{X} 4 \mathrm{t}-1++\mu \mathrm{t} .
$$

2. Restricted and VEC model

Error Correction term - co-integrating equation and long-run model

ECTt-1 $=$ X1t $-[C 1+\alpha 1 \mathrm{X} 1 \mathrm{t}-1+\alpha 2 \mathrm{X} 2 \mathrm{t}-1+\alpha 3 \mathrm{X} 3 \mathrm{t}-1+\alpha 4 \mathrm{X} 4 \mathrm{t}-1]$

3. Target Variable

$$
\Delta \mathrm{X} 1 \mathrm{t}=\mathrm{C} 1+\alpha 1 \mathrm{X} 1 \mathrm{t}-1+\alpha 2 \mathrm{X} 2 \mathrm{t}-1+\alpha 3 \mathrm{X} 3 \mathrm{t}-1+\alpha 4 \mathrm{X} 4 \mathrm{t}-1+\lambda \mathrm{ECTt}-1
$$

where $\lambda$ is the speed of adjustment.

\subsubsection{AutoRegression Model Stability and Residuals Tests}

Characteristics of a good time series regression require several tests on the equations estimated. The Best Linear Unbiased Estimator (BLUE) properties testing checks for error term's distribution, mean, and variance and applies to the estimated equation. The tests entailed the following,

1. Stability Diagnostics: - The test objective is to determine the stability of the dependent variable, in this case, the real GDP. The result determines whether the independent parameter's coefficients systematically change from recursive tests based on recursive tests of the Cumulative sum of Squares (CUSUM). In this case, the test hypothesis was,

$\mathrm{H}_{0}$ : Parameters are stable (Desirable) and $\mathrm{H}_{\mathrm{A}}$ : Parameters are not stable (Not Desirable)

2. Residual Diagnostics: - Assumption is that residual errors are independent of each other, have similar unknown variance (homoscedasticity), and have a mean zero with a normal distribution. Therefore, the following tests,

a) Serial Correlation: The test ensured no correlation in real GDP, public investment, private domestic investment, and public-private partnership investment in the estimated equation residues. If autocorrelation exists, the nature of autocorrelation would determine the remedy for adoption. Serial correlation may come from specification bias of the model such as the exclusion of important variables, incorrect functional form, and lags used, etc. BreuschGodfrey test that applies to the error term $\mathrm{u}_{\mathrm{t}}$ with pth-order autoregressive hypothesis testing, 
ut $=\rho 1$ ut $-1+\rho 2 u t-2+\ldots \ldots \ldots+\rho$ put-p $+\varepsilon t$, and $\varepsilon t$ as the white noise.

The hypothesis to test being, where, $\mathrm{H}_{0}: \rho 1=\rho 2=\ldots . .=\rho p=0$ and $\mathrm{H}_{\mathrm{A}}: \rho 1 \neq \rho 2$ $\neq \ldots . .=\rho p \neq 0$

b) Heteroskedasticity: - A plot of the error term (residuals) against real GDP shows the nature of the distribution of error terms over time. The variance of residual terms being constant from the estimated equation (homoskedasticity); is a property desired for Best Linear Unbiased Estimate properties. Otherwise, a changing variance means Heteroscedasticity that is undesirable and may result in a biased standard error and incorrect conclusion about the significance of regression coefficients. The test applied was Breusch-Pagan-Godfrey. The hypothesis was,

Ho: Residuals are not heteroskedastic (Homoscedastic)

$\mathbf{H}_{\mathrm{A}}$ : Residuals are heteroskedastic

c) Residual Normality Test: Another of the BLUE properties for the estimated model was residuals testing for normal distribution. Jacque Bera normality test at $5 \%$ significance level test affirms normality and was used as the preferred test.

\subsubsection{Internal Investment Causality Tests}

The VAR model specification for all the four variables considered as endogenous went through the Granger causality test. The main target was the nexus between internal investments and real GDP. In addition, other variables of public investment, private domestic investment, and public-private partnership investment had Granger causality tests to verify influence among themselves. The basis was on the assumption that real GDP may also have causality to the other internal investment variables. The study performed both pairwise and block Granger causality based on the significance of the p-value of 5\%; an example for the real GDP hypothesis as below,

H0: Real GDP does cause Granger causality on Public investment

H1: Real GDP does not cause Granger causality on Public investment.

\subsubsection{Variance Decomposition of the Forecast error of Internal Investments}

Variance decomposition of the forecast error in the VAR model requires time series data to be stationary with the optimal lag selection for the VAR system model already determined. Variance decomposition aid in assessing the percentage of unexplained error variation of other endogenous variables resulting from a unit shock from the target variable in the VAR system model. The objective was to determine the relative impact of an internal investment would have on another investment or real GDP. This would help to assess linkage to economic growth significance of the impact as a percentage of the forecast error by a description of 
weak and strong influence both for the short-run and long-run dynamics over time. Variance decomposition of forecast error from GDP shock to real GDP (own shock), public investment, private domestic investment, and public-private partnership investment. Variance decomposition of forecast error from Public Investment shock to real GDP, public investment (own shock), private domestic investment, and public-private partnership investment. Variance decomposition of forecast error from Private Domestic Investment shock to real GDP, public investment, private domestic investment (own shock), and public-private partnership investment. Then finally, variance decomposition of forecast error from Public-Private Partnership Investment to real GDP, public investment, private domestic investment, and public-private partnership investment (own shock).

\subsubsection{Impulse Response Function of Internal Investment Variables}

The variables $\mathrm{X} 1, \mathrm{X} 2, \mathrm{X} 3$, and $\mathrm{X} 4$ that are real GDP, public investment, private domestic investment, and public-private partnership investment respectively are endogenous variables that impulse shocks did apply for application against their lagged values. The objective was to identify the responsiveness of the dependent variables (all endogenous variables in ARDL) when applied to a unit shock to their error terms. The ordering of the variables was on real GDP, public investment, private domestic investment, and public-private partnership investment in that order based on Cholesky degrees of freedom (d.o.f.) adjusted provided in Eviews. In this case, the shocks would be $\mu 1, \mu 2, \mu 3$, and $\mu 4$ for the whole VAR system as shown below.

Model 1: $\underline{\mathbf{X}_{1 t}}=\mathrm{C}_{1}+\underline{\boldsymbol{\alpha}_{1}} \underline{\mathbf{X}}_{1 \mathrm{t}-1}+\alpha_{2} \mathrm{X}_{2 \mathrm{t}-1}+\alpha_{3} \mathrm{X}_{3 \mathrm{t}-1}+\alpha_{3} \mathrm{X}_{4 \mathrm{t}-1}+\boldsymbol{\mu}_{1}$.

Model 2: $\underline{\mathbf{X}_{2 t}}=C_{2}+\beta_{1} X_{1 t-1}+\underline{\beta}_{2} \underline{X}_{1 t-1}+\beta_{3} X_{2} t-1+\beta_{3} X_{3} t-1+\mu_{2}$

Model 3: $\underline{\mathbf{X}_{3 t}}=\mathrm{C}_{3}+\varphi_{1} \mathrm{X}_{1 \mathrm{t}-1}+\varphi_{2} \mathrm{X}_{1} \mathrm{t}-1+\underline{\boldsymbol{\varphi}_{3} \mathbf{X}_{2} \mathrm{t}-1}+\varphi_{4} \mathrm{X}_{3} \mathrm{t}-1+\boldsymbol{\mu}_{4}$.

Model 4: $\underline{\mathrm{X}_{4 \mathrm{t}}}=\mathrm{C}_{4}+\tau_{1} \mathrm{X}_{1 \mathrm{t}-1}+\tau_{2} \mathrm{X}_{1 \mathrm{t}-1}+\tau_{3} \mathrm{X}_{3 \mathrm{t}-1}+\underline{\tau_{4} \mathrm{X}_{4 \mathrm{t}-1}}+\boldsymbol{\mu}_{4}$

Note:

The underlined value is the lagged variable of the dependent variable and the order remains the same.

\subsection{Internal Investment Empirical Investigation Measurements}

The dependent target variable being real GDP, the main objective was to determine the nexus between internal investments and economic growth. Hence, the findings will inform the discussion on the following. Unit roots result in the stationarity nature of time series data of internal investment and real GDP growth. The optimal lag structure for real GDP and internal investment to apply on time series data between the years 1996 and 2017. Co-integration test results were to determine the AutoRegression model to consider for analysis from variables co-integration 
relationship. Resulting analysis specification for short-run and long-run dynamics inference. Statistical significance establishment of internal investment variables influences on real GDP. Granger Causality to establish a joint lag structure influence on the real GDP from internal investment variables and among them. Variance decomposition to provide short-run and long-run effects from shocks (innovation) to real GDP and other internal investment variables over a period. Finally, impulse response function to provide effects of unit shocks (innovation) overall influence on the VAR model system over time. In conclusion, the results from these econometric analyses will provide a full empirical investigation needed to guide nexus arguments of internal investment influences on economic growth.

\section{Main Results}

\subsection{Normalization for the raw data}

Public investment and private domestic investment (based on domestic savings as the proxy) came from the computation of the percentages of fixed gross capital formation of GDP provided by the Knoema website organization. Short-term Treasury bills rate, commercial lending rates, and Real GDP came from CBK maintained database. Real interest rates came from the World Bank database. Public-private partnership investments and country risk premiums came from the World Bank database. The country risk premium on lending was used in the proxy for CAPM.

By using the percentage of fixed gross capital formation and deflator values for each year, this helped to get formative real public investment and private domestic investment values. Public-private partnership investment data for some years was not available from the World Bank Data source but country risk premium on lending was available for the entire period. For the data to conform to the analysis format required by the analysis application software, this required some normalization of the data where,

1. Negative values in Real interest rate (in years 1996, 2006, and 2008) and public investments (the year 2009) required adding the least value to each of the data for all the years to make them positive to be usable by the log function.

2. For the missing data, this required using the Log-Linear algorithm function for interpolation to fill up missing data in the public-private partnership investment.

Table 2 is a presentation of raw data without any modification while Table 3 that follows is a representation of the normalized data used for analysis. 
Table 2: Raw Data for Analysis before Normalization

\begin{tabular}{|c|c|c|c|c|c|c|c|c|}
\hline Year & $\begin{array}{c}\text { Real GDP } \\
\text { (LCU } \\
\text { Millions) }\end{array}$ & $\begin{array}{c}\text { Real } \\
\text { Interest } \\
\text { Rate } \\
(\boldsymbol{\%})\end{array}$ & $\begin{array}{c}\text { Public } \\
\text { Investment } \\
\text { (LCU Millions) }\end{array}$ & $\begin{array}{c}\text { Treasury } \\
\text { Bills } \\
\text { Rate } \\
\mathbf{( 8 \% )}\end{array}$ & $\begin{array}{l}\text { Domestic } \\
\text { Private } \\
\text { Investment } \\
\text { (LCU Millions) }\end{array}$ & $\begin{array}{c}\text { Commercial } \\
\text { Lending } \\
\text { Interest } \\
\text { Rates (\%) }\end{array}$ & $\begin{array}{c}\text { Public-Private } \\
\text { Partnership } \\
\text { Investments } \\
\text { (Millions) }\end{array}$ & $\begin{array}{c}\text { Country } \\
\text { Risk } \\
\text { Lending } \\
\text { Premium } \\
\text { (\%) }\end{array}$ \\
\hline 1996 & $920,190.00$ & -0.06 & $39,635.80$ & 0.23 & $64,833.70$ & 0.28 & $10,098.00$ & 10.78 \\
\hline 1997 & $24,560.00$ & 0.17 & $41,861.64$ & 0.22 & $68,011.57$ & 0.28 & - & 7.75 \\
\hline 1998 & $954,980.00$ & 0.21 & $41,706.93$ & 0.23 & $72,171.70$ & 0.29 & $5,446.80$ & 6.17 \\
\hline 1999 & $976,996.00$ & 0.17 & $41,138.98$ & 0.13 & $71,822.20$ & 0.22 & $14,178.00$ & 9.09 \\
\hline 2000 & $982,855.00$ & 0.15 & $44,325.54$ & 0.12 & $72,255.20$ & 0.22 & - & 10.27 \\
\hline 2001 & $1,020,111.00$ & 0.18 & $149,976.77$ & 0.13 & $78,010.30$ & 0.20 & - & 6.94 \\
\hline 2002 & $1,025,583.00$ & 0.17 & $103,485.06$ & 0.09 & $79,587.70$ & 0.19 & - & 9.51 \\
\hline 2003 & $1,055,658.00$ & 0.10 & $118,594.78$ & 0.04 & $82,572.67$ & 0.16 & - & 12.84 \\
\hline 2004 & $1,109,338.00$ & 0.05 & $89,442.40$ & 0.03 & $133,052.63$ & 0.13 & - & 9.57 \\
\hline 2005 & $1,172,784.00$ & 0.08 & $44,983.60$ & 0.08 & $190,052.04$ & 0.13 & 44.59 & 4.45 \\
\hline 2006 & $1,249,470.00$ & -0.08 & $34,091.07$ & 0.07 & $230,298.97$ & 0.14 & $57,140.40$ & 6.82 \\
\hline 2007 & $1,336,849.00$ & 0.05 & $3,047.83$ & 0.07 & $261,357.01$ & 0.13 & $1,530.00$ & 6.54 \\
\hline 2008 & $1,357,262.00$ & -0.01 & $44,449.65$ & 0.08 & $246,332.83$ & 0.14 & $20,910.00$ & 6.31 \\
\hline 2009 & $2,863,689.00$ & 0.03 & $-5,389.13$ & 0.07 & $415,641.21$ & 0.15 & $12,954.00$ & 7.43 \\
\hline 2010 & $3,104,303.00$ & 0.12 & $91,773.86$ & 0.04 & $438,492.07$ & 0.14 & & - \\
\hline 2011 & $3,294,026.00$ & 0.04 & $121,854.06$ & 0.09 & $446,891.34$ & 0.15 & $17,309.40$ & 6.32 \\
\hline 2012 & $3,444,339.00$ & 0.09 & $195,342.95$ & 0.13 & $431,749.49$ & 0.20 & $36,720.00$ & 7.14 \\
\hline 2013 & $3,646,821.00$ & 0.12 & $298,985.39$ & 0.09 & $350,407.1$ & 0.17 & $53,754.00$ & 8.39 \\
\hline 2014 & $3,842,186.00$ & 0.08 & $397,174.23$ & 0.09 & $404,882.50$ & 0.17 & $77,928.00$ & 7.58 \\
\hline 2015 & $4,061,901.00$ & 0.06 & $354,517.19$ & 0.11 & $462,579.52$ & 0.16 & & - \\
\hline 2016 & $4,300,699.00$ & 0.10 & $222,161.08$ & 0.09 & $530,753.57$ & 0.17 & $17,136.00$ & 8.16 \\
\hline 2017 & $4,509,822.00$ & 0.03 & $322,483.22$ & 0.08 & $472,979.83$ & 0.14 & $9,882.78$ & 5.30 \\
\hline
\end{tabular}


Table 3: Resultant Data After Normalization

\begin{tabular}{|l|l|l|l|l|l|l|l|l|}
\hline Year & $\mathbf{X 1}$ & $\mathbf{E} 1$ & $\mathbf{X 2}$ & $\mathbf{E 2}$ & $\mathbf{X 3}$ & $\mathbf{E 3}$ & $\mathbf{X} 4$ & $\mathbf{E 4}$ \\
\hline 1996 & $920,190.000$ & 0.023 & $45,027.930$ & 0.230 & $64,833.700$ & 0.282 & $10,098.000$ & 10.783 \\
\hline 1997 & $924,560.000$ & 0.250 & $47,253.770$ & 0.225 & $68,011.570$ & 0.283 & $7,416.320$ & 7.753 \\
\hline 1998 & $954,980.000$ & 0.292 & $47,099.060$ & 0.233 & $72,171.700$ & 0.295 & $5,446.800$ & 6.167 \\
\hline 1999 & $976,996.000$ & 0.256 & $46,531.110$ & 0.133 & $71,822.200$ & 0.224 & $14,178.000$ & 9.095 \\
\hline 2000 & $982,855.000$ & 0.234 & $49,717.670$ & 0.121 & $72,255.200$ & 0.223 & $5,426.900$ & 10.274 \\
\hline 2001 & $1,020,111.000$ & 0.259 & $155,368.898$ & 0.127 & $78,010.300$ & 0.197 & $2,077.250$ & 6.936 \\
\hline 2002 & $1,025,583.000$ & 0.255 & $108,877.191$ & 0.089 & $79,587.700$ & 0.185 & 795.110 & 9.511 \\
\hline 2003 & $1,055,658.000$ & 0.179 & $123,986.912$ & 0.037 & $82,572.667$ & 0.164 & 304.340 & 12.842 \\
\hline 2004 & $1,109,338.000$ & 0.132 & $94,834.526$ & 0.030 & $133,052.631$ & 0.125 & 116.490 & 9.572 \\
\hline 2005 & $1,172,784.000$ & 0.157 & $50,375.730$ & 0.084 & $190,052.035$ & 0.129 & 44.590 & 4.446 \\
\hline 2006 & $1,249,470.000$ & 0.001 & $39,483.203$ & 0.068 & $230,298.966$ & 0.136 & $57,140.400$ & 6.822 \\
\hline 2007 & $1,336,849.000$ & 0.129 & $8,439.960$ & 0.068 & $261,357.012$ & 0.133 & $1,530.000$ & 6.541 \\
\hline 2008 & $1,357,262.000$ & 0.071 & $49,841.785$ & 0.077 & $246,332.827$ & 0.140 & $20,910.000$ & 6.314 \\
\hline 2009 & $2,863,689.000$ & 0.109 & 2.999 & 0.074 & $415,641.207$ & 0.148 & $12,954.000$ & 7.429 \\
\hline 2010 & $3,104,303.000$ & 0.201 & $97,165.988$ & 0.036 & $438,492.071$ & 0.144 & $14,974.180$ & 10.770 \\
\hline 2011 & $3,294,026.000$ & 0.119 & $127,246.194$ & 0.087 & $446,891.344$ & 0.150 & $17,309.400$ & 6.323 \\
\hline 2012 & $3,444,339.000$ & 0.176 & $200,735.081$ & 0.128 & $431,749.486$ & 0.196 & $36,720.000$ & 7.143 \\
\hline 2013 & $3,646,821.000$ & 0.197 & $304,377.522$ & 0.089 & $350,407.126$ & 0.173 & $53,754.000$ & 8.388 \\
\hline 2014 & $3,842,186.000$ & 0.159 & $402,566.364$ & 0.089 & $404,882.497$ & 0.165 & $77,928.000$ & 7.583 \\
\hline 2015 & $4,061,901.000$ & 0.136 & $359,909.320$ & 0.109 & $462,579.521$ & 0.162 & $36,542.770$ & 5.160 \\
\hline 2016 & $4,300,699.000$ & 0.185 & $227,553.210$ & 0.085 & $530,753.569$ & 0.166 & $17,136.000$ & 8.047 \\
\hline 2017 & $4,509,822.000$ & 0.109 & $327,875.347$ & 0.084 & $472,979.826$ & 0.137 & $9,882.780$ & 5.296 \\
\hline Key & & & & & & & & \\
\hline
\end{tabular}

Key:

\begin{tabular}{|l|l|}
\hline X1 = Real GDP & E1 = Real Interest Rates \\
\hline X2 = Public Investments & E2 $=$ Short-term treasury bills \\
\hline X3 = Private Domestic Investments & E3 = Commercial Lending Interest Rates \\
\hline X4 = Public-Private Partnership Investment & E4 = Country Risk Premium on Lending \\
\hline
\end{tabular}

\subsection{Specific Research Findings}

\subsubsection{Stationarity Tests}

Using normalized data in Table 3 of time-series data, the stationarity test applied Augmented Dickey-Fuller (ADF) tests by comparing the t-statistic value against the critical value and too considered comparison of $\mathrm{R}^{2}$ against Durbin - Watson statistic. Table 4 gives the Unit Root Test results for stationarity for both endogenous and exogenous variables. 
Table 4: Unit Root Test Results

\begin{tabular}{|c|c|c|c|c|c|c|}
\hline Variable & Type & t-statistic & $\begin{array}{c}\text { Test } \\
\text { Critical } \\
\text { Value at 5\% }\end{array}$ & Probability & Level & $\begin{array}{c}\text { R2 }<\text { Durbin- } \\
\text { Watson Stat. }\end{array}$ \\
\hline Real GDP & $\begin{array}{c}\text { Dependent } \\
\text { Endogenous }\end{array}$ & -4.390523 & -3.02686 & 0.0029 & I (1) & $0.517124<2.0007545$ \\
\hline $\begin{array}{c}\text { Real Interest } \\
\text { Rates }\end{array}$ & Exogenous & -4.473795 & -3.012363 & 0.0022 & I (1) & $0.513006<1.906648$ \\
\hline $\begin{array}{c}\text { Public } \\
\text { investment }\end{array}$ & $\begin{array}{c}\text { Independent } \\
\text { (Endogenous) }\end{array}$ & -3.818878 & -3.012363 & 0.0094 & I (0) & $0.434252<2.028960$ \\
\hline $\begin{array}{c}\text { Treasury Bills } \\
\text { Rate }\end{array}$ & Exogenous & -4.745415 & -3.029970 & 0.0015 & I (1) & $0.639845<1.820053$ \\
\hline $\begin{array}{c}\text { Domestic } \\
\text { Private } \\
\text { Investments }\end{array}$ & $\begin{array}{c}\text { Independent } \\
\text { Endogenous }\end{array}$ & -3.621102 & -3.020686 & 0.0148 & I (1) & $0.421452<1.922208$ \\
\hline $\begin{array}{c}\text { Commercial } \\
\text { Lending } \\
\text { Interest Rates }\end{array}$ & Exogenous & -4.217683 & -3.020686 & 0.0042 & I (1) & $0.497050<1.917707$ \\
\hline $\begin{array}{c}\text { Public-private } \\
\text { partnership } \\
\text { investment }\end{array}$ & $\begin{array}{c}\text { Independent } \\
\text { Endogenous } \\
\text { (After } \\
\text { interpolation) }\end{array}$ & -7.190867 & -3.020686 & 0.0000 & I (1) & $0.741782<1.965369$ \\
\hline $\begin{array}{c}\text { The country } \\
\text { Risk premium } \\
\text { on lending }\end{array}$ & Exogenous & -4.062208 & -3.012363 & 0.0055 & I (1) & $0.464812<1.889474$ \\
\hline
\end{tabular}

Stationarity tests showed endogenous variables of real GDP, domestic private investments, and public-private partnership investment integrated at I (1); while public investment integrated at I (0). Exogenous variables corresponding to these endogenous variables for real GDP, public investments, and domestic private investment showed all integrated at I (1). The essence of the Durbin-Watson statistic and $\mathrm{R}^{2}$ comparison was to safeguard against spurious regression. As a rule of thumb, if $\mathrm{R}^{2}$ is greater than the Durbin-Watson statistic, then a spurious regression may result (Granger and Newbold, 1974).

\subsubsection{Optimal Lag Structure}

Two optimal lag structure results were determined, one for the entire model and individual variables. Except for the public investment equation, the other independent variables equations showed an optimal lag structure of value 1. Table 5, shows Akaike Information Criteria (AIC), $\mathrm{R}^{2}$ and the optimal lag for each regression. 
Table 5: Optimal Lag Structure

\begin{tabular}{|l|c|l|c|}
\hline \multicolumn{1}{|c|}{ Module } & \multicolumn{1}{|c|}{$\begin{array}{c}\text { Information } \\
\text { Criterion }\end{array}$} & \multicolumn{1}{|c|}{$\mathbf{R}^{\mathbf{2}}$} & $\begin{array}{c}\text { Optimal } \\
\text { Lag }\end{array}$ \\
\hline $\begin{array}{l}\text { Target Vector } \\
\text { AutoRegression model }\end{array}$ & $\begin{array}{c}\text { AIC: }=2.513379 \\
\text { Schwarz }=5.102283\end{array}$ & $\begin{array}{l}\text { Real GDP }=0.961436 \\
\text { Public Investment }=0.588043 \\
\text { Domestic Investment }=0.974818 \\
\text { PPP Investment }=0.967964\end{array}$ & 1 \\
\hline Real GDP & AIC $=-0.504028$ & 0.935707 & 1 \\
\hline Public Investments & AIC $=4.975945$ & 0.057880 & 0 \\
\hline Domestic Investments & AIC $=-0.322823$ & 0.950356 & 1 \\
\hline $\begin{array}{l}\text { Public-Private } \\
\text { Partnership Investments }\end{array}$ & AIC $=4.238135$ & 0.358299 & 1 \\
\hline
\end{tabular}

\subsubsection{Co-integration Tests}

Since the results of time-series stationarity tests showed a mix of integration of order I (1) and I (0), then Johansen co-integration test became inadmissible. The ARDL co-integration bounds test proposed by Pesaran, Shin and Smith (2001) became an appropriate co-integration test method for this analysis. Hypothesis being - H0: no co-integration and HA: co-integrated. In this case, co-integration results being to reject the null hypothesis at either $10 \%, 5 \%$, or $1 \%$ significant bounds limits provided. The decision based on such that, 1) if F- statistic is greater than the upper bound value of I(1), then there's co-integration; 2) if F- statistic is less than the lower bound value of $\mathrm{I}(0)$, then there is no co-integration; Otherwise if F- statistic is between $\mathrm{I}(0)$ and $\mathrm{I}(1)$ bound values, co-integration test is inconclusive. The results for bounds co-integration tests for these variables tests using F-statistic are in Table 6.

Table 6: Co-integration ARDL Bounds Test

\begin{tabular}{|l|l|l|l|l|l|}
\hline $\begin{array}{l}\text { Dependent } \\
\text { Variable }\end{array}$ & F-statistic & $\begin{array}{c}\text { Lower } \\
\text { Bound } \\
\text { I (0) }\end{array}$ & $\begin{array}{c}\text { Upper } \\
\text { Bound } \\
\mathbf{1}(\mathbf{1})\end{array}$ & $\begin{array}{c}\text { F-statistic } \\
\text { Comparison }\end{array}$ & \multicolumn{1}{|c|}{ Implication } \\
\hline Real GDP & 60.29036 & 4.68 & 5.98 & F-stat > I (1) & $\begin{array}{l}\text { Co-integrated=Yes } \\
\text { Estimate ECM }\end{array}$ \\
\hline $\begin{array}{l}\text { Public } \\
\text { Investment }\end{array}$ & 103.6154 & 3.23 & 4.35 & F-stat > I (1) & $\begin{array}{l}\text { Co-integrated=Yes } \\
\text { Estimate ECM }\end{array}$ \\
\hline $\begin{array}{l}\text { Domestic } \\
\text { Private } \\
\text { Investment }\end{array}$ & 4.712507 & 4.683 & 5.98 & F-stat > I (1) & $\begin{array}{l}\text { Co-integrated =Yes } \\
\text { Estimate ECM }\end{array}$ \\
\hline $\begin{array}{l}\text { Public } \\
\text { Private } \\
\text { Investment }\end{array}$ & 2.812991 & 3.71 & 5.018 & F-stat < I (0) & $\begin{array}{l}\text { Co-integrated = No } \\
\text { Estimate ECM }\end{array}$ \\
\hline
\end{tabular}

The co-integration bounds test indicated that three equations relating to Real GDP, public investment, and domestic investment were co-integrated. Therefore, requiring error correction model (ECM) i.e. to estimate both short-run and long-run 
equations for dynamic equilibrium. The results showed public-private partnership investment required no ECM estimation since F-statistic was below the lower bound; implying no co-integration.

\subsubsection{ARDL and ECM Estimation}

The results from regression equations using ARDL for the three co-integrated equations (from Table 6), for the target equation of real GDP, the public investment, and private domestic investment requiring error correction term and public-private partnership investments with no ECM are as in Table 7. Column 1 is the dependent variable, column 2 the constant, then the lagged values are into two main columns of endogenous and exogenous variables. For each equation, each coefficient t-statistic, probability(significance), $\mathrm{R}^{2}$, Durbin-Watson and equation probability. Last column provides speed of adjustment of short-run adjustment for the long-run to equilibrium.

Table 7: Comparison of significant independent variables (t-statistic)

\begin{tabular}{|c|c|c|c|c|c|c|c|c|c|c|c|}
\hline \multirow{2}{*}{\multicolumn{2}{|c|}{ ARDL Estimate }} & \multirow[b]{2}{*}{$\mathbf{C}$} & \multicolumn{4}{|c|}{ Endogenous Variables } & \multicolumn{5}{|c|}{ Exogenous Variables } \\
\hline & & & X1(-1) & $\mathrm{X} 2(-1)$ & X3(-1) & X4(-1) & E1(-1) & E2(-1) & E3(-1) & E4(-1) & ECT (-1) \\
\hline \multirow{4}{*}{$\begin{array}{c}\text { Real } \\
\text { GDP (X1) }\end{array}$} & Coefficient & -0.0173 & 0.831 & 0.037 & 0.191 & -0.041 & & - & 0.170 & 0.075 & \multirow{3}{*}{$\begin{array}{l}28.29 \% \\
p=0.4952\end{array}$} \\
\hline & t-statistic & -0.018 & 8.123 & 2.833 & 2.686 & -1.451 & & - & 2.031 & 2.000 & \\
\hline & Probability & 0.986 & 0.0002 & 0.030 & 0.036 & 0.197 & & - & 0.089 & 0.093 & \\
\hline & \multicolumn{11}{|c|}{$\mathrm{R}^{2}=0.999823$, Durbin-Watson stat $=2.051111$, Prob $(\mathrm{F}$-statistic $)=0.000000$} \\
\hline \multirow{4}{*}{$\begin{array}{c}\text { Public } \\
\text { Investment } \\
\text { (X2) }\end{array}$} & Coefficient & -191.893 & 21.529 & -0.692 & -7.256 & -0.339 & 0.210 & & - & -1.131 & \multirow{3}{*}{$\begin{array}{l}29.04 \% \\
p=0.6189\end{array}$} \\
\hline & t-statistic & -3.131 & 4.332 & -2.758 & -7.704 & -3.432 & -1.421 & & - & -1.633 & \\
\hline & Probability & 0.014 & 0.003 & 0.025 & 0.0001 & 0.009 & 0.193 & & - & 0.141 & \\
\hline & \multicolumn{11}{|c|}{$\mathrm{R}^{2}=0.990525$, Durbin-Watson stat $=2.078591$, Prob $(\mathrm{F}$-statistic $)=0.000001$} \\
\hline \multirow{4}{*}{$\begin{array}{l}\text { Private } \\
\text { Domestic } \\
\text { (X3) }\end{array}$} & Coefficient & -1.485 & 0.214 & 0.069 & 0.768 & 0.011 & 0.089 & 0.089 & & 0.174 & \multirow{3}{*}{$\begin{array}{l}79.40 \% \\
p=0.2098\end{array}$} \\
\hline & t-statistic & -1.202 & 1.425 & 3.595 & 6.274 & 1.547 & -0.714 & 1.441 & & 1.411 & \\
\hline & Probability & 0.296 & 0.227 & 0.023 & 0.003 & 0.197 & 0.515 & 0.223 & & 0.231 & \\
\hline & \multicolumn{11}{|c|}{$\mathrm{R}^{2}=0.999859$, Durbin-Watson stat $=2.399850$, Prob $(\mathrm{F}$-statistic $)=0.000001$} \\
\hline \multirow{4}{*}{$\begin{array}{c}\text { Public } \\
\text { Private } \\
\text { Partnership } \\
\text { (X4) }\end{array}$} & Coefficient & 7.214 & -3.179 & 0.018 & 4.559 & 0.075 & 0.453 & 2.367 & 1.392 & & \multirow{3}{*}{$\begin{array}{l}\text { No co- } \\
\text { integration }\end{array}$} \\
\hline & t-statistic & 0.613 & -1.596 & 0.159 & 2.509 & 0.299 & 1.494 & 2.205 & 0.366 & & \\
\hline & Probability & 0.551 & 0.134 & 0.876 & 0.026 & 0.770 & 0.159 & 0.046 & 0.721 & & \\
\hline & \multicolumn{11}{|c|}{$\mathrm{R}^{2}=0.793090$. Durbin-Watson stat $=2.220169$, Prob $($ F-statistic $)=0.001273$} \\
\hline
\end{tabular}


1. Real GDP - Real GDP(X1) regression estimation takes into account a structural break in the year 2008, therefore introducing dummy variables. The distributed lag of real GDP (X1) showed a very high statistically significant impact on real GDP. While public investments (X2) and private investments (X3) indicated a highly significant impact too on real GDP. Commercial lending rates (E3) and the country risk premium on lending (E4) showing less significance and approaching statistically significant influence on real GDP at $10 \%$. The publicprivate partnership (X4) showed the least significant among the explanatory variables with a negative coefficient influence on real GDP. Short-run disturbances adjustment towards long-run equilibrium was at $28.29 \%$. The longrun adjustment should be significant while in this case, it was insignificant. This means the disequilibrium in the short run as not corrected in the period nor extended into the next lagged period. The $\mathrm{R}^{2}$ value of 0.999 showed that the real GDP dependent variable explained by the independent variables as specified. While the Durbin-Watson test showed, there was almost no correlation within the variables since $\mathrm{R}^{2}$ is less than the Durbin-Watson statistic as a test for spurious regression results.

2. Public Investment: There was a structural change that affected public investments in the year 2009 which was due to the rebasing year of the country's GDP. Therefore, creating a dummy variable to cater to this structural change. According to Table 5 for public investment regression, except for the positive significant lagged value of real GDP (X1), all the other variables coefficients are negative; which means decreased investment from lagged public investment (itself), private domestic investment, and public-private partnership investment, with all to lead to a positive public investment. In the same finding, the autonomous public investment showed a big negative value that was also significant with a p-value of 0.014 . Reduction in private domestic investment (X3) showed a high statistic significant influence on increasing public investment. Country risk premium on lending (E4) and real interest rates (E1) showing little significance but more insignificant in real interest rates (E1). However, adjustment to the long-run equilibrium was at $29.04 \%$ and insignificant. The value of R2 is high enough and it's also less than the DurbinWatson statistic.

3. Private Domestic Investment: Two structural change effects showed in the time series data in the years 2003 and 2007 for private domestic investments. Introduction of dummy values catered for the structural changes in the analysis. ARDL equation estimation from Table 5 showed lagged domestic investment (X3), and public investment had a statistically positive significant influence on domestic investment (X3). While public-private partnership investment (X4) and real GDP (X1) had a slight significant impact on private domestic investment too. Reduction in real interest rates (E1), increase in treasury bills rate (E2), and the country risk premium on lending (E4) had a positive impact 
on private domestic investment though insignificant at 5\%. Treasury bills rate (E2) and the country risk premium on lending positive value could be an effect of declining real interest rate therefore demand for domestic investments. Longrun adjustment by private domestic investment stood at $79.41 \%$ towards equilibrium while being insignificant but highest among the other variables. Meaning the short-run disturbances as not corrected before the next period.

4. Public-Private Partnership Investment: Estimation for public-private partnership investment showed a lagged private domestic investment (X3) and treasury bills rate (E2) as the only statistically significant regressing influencers. Real GDP and real interest rates also had a slight significant contribution even though a reduction in the real GDP. Public investment and itself had an insignificant influence on public-private partnerships (own lag). Long-run ECM was not applicable because the bounds test showed no co-integration.

\subsubsection{Auto-Regression Model Stability and Residuals Tests}

Based on the ARDL estimated equations, model stability, and residual tests, tested at $5 \%$ significance, gave results as summarized in Table 8.

Table 8: Model Stability and Residual Diagnostics

\begin{tabular}{|l|l|l|l|l|l|l|}
\hline \multirow{2}{*}{$\begin{array}{l}\text { Equation Estimate } \\
\begin{array}{l}\text { Variable } \\
\text { (Variable Abbrev) }\end{array}\end{array}$} & \multicolumn{6}{|c|}{ Residuals Diagnostic } \\
\cline { 2 - 7 } & F-statistic & Probability & F-Statistic & Probability & Jarque Bera & Probability \\
\hline $\begin{array}{l}\text { Real GDP } \\
\text { LOG (X1) }\end{array}$ & 1.327951 & 0.3863 & 0.275773 & 0.9741 & 0.502746 & 0.777732 \\
\hline $\begin{array}{l}\text { Public investment } \\
\text { LOG (X2) }\end{array}$ & 0.291635 & 0.6059 & 0.715971 & 0.7031 & 1.130010 & 0.568357 \\
\hline $\begin{array}{l}\text { Private Domestic } \\
\text { Investment } \\
\text { LOG (X3) }\end{array}$ & 7.042803 & 0.0767 & 0.650585 & $0 . .7581$ & 0.203729 & 0.903152 \\
\hline $\begin{array}{l}\text { Public-private } \\
\text { partnership Investment } \\
\text { LOG (X4) }\end{array}$ & Graphical & & 0.697931 & 0.6559 & 0.502685 & 0.777756 \\
\hline
\end{tabular}

From the results, all the estimated equations for CUSUM of squares of the residuals showed stability, no serial correlation, heteroskedasticity, and residues normality as shown in Table 9. 
Table 9: Stability of ARDL Residual Tests

\begin{tabular}{|l|c|c|c|}
\hline \multirow{2}{*}{$\begin{array}{l}\text { Equation Estimate } \\
\text { Variable }\end{array}$} & $\begin{array}{c}(\mathbf{c} \text { Model Stability } \\
\text { Coefficient Stability } \\
\text { (CUSUM) }\end{array}$ & $\begin{array}{c}\text { (2) } \\
\text { Residual Variance } \\
\text { (CUSUM of Squares) }\end{array}$ & $\begin{array}{c}\text { (3) } \\
\text { Verdict }\end{array}$ \\
\hline Real GDP & Stable & Stable & Ok \\
\hline Public Investments & Stable & Stable & Ok \\
\hline $\begin{array}{l}\text { Private Domestic } \\
\text { Investment }\end{array}$ & Stable & Stable & Ok \\
\hline $\begin{array}{l}\text { Public-Private Partnership } \\
\text { Investment }\end{array}$ & Stable & Stable & Ok \\
\hline
\end{tabular}

\subsubsection{Internal Investments and real GDP Causality Analysis}

Table 10, provides two distinct tests of causality. The first major column provides pairwise Granger causality results and the second major column provides block exogeneity causality using Wald Test. The causality in Table 10 also compares to the results of significance in estimated equations in Table 7.

When comparing Table 7 and Table 10 between statistical coefficients significance from and Granger causality respectively tables, they display some relationships from the analysis which can deduce some causality inferences. Table 7 showed some significant elements of real GDP ARDL equations significant influence on public investment that comes as pairwise causality in Table 9. In Table 7, all the endogenous significant independent variables in public investment showed some form of expectation of the Wald Test for Block exogeneity influence as shown in Wald Test chi-square probability block exogeneity causality.

The significant influence of public investment (X2) (0.030) on real GDP (X1) and significant influence of real GDP(X1) (0.0026) provides a hint that there could be Granger causality between the two. Pairwise Granger Causality hypothesis that real GDP(X1) does not cause Granger Cause public investment (X2) hypothesis rejection; confirmed in Table 10 in column (1). The F-statistical probability of 0.0277 is less than 5\%, meaning it is significant and hence pairwise Granger causality. This confirms that real GDP (X1) does cause Granger causality on public investments (X2). Otherwise, there is no pairwise Granger causality in all the other variables. The Wald Test (Block Wise) showed that public investments (X2) have Granger causality significant at 0.0345 which is within a 5\% significant level. By referencing the statistical significance in Table 10 in column (2), it also showed there could be block Granger causality for public investment as the dependent variable. There is no other dependent variable on Granger causality that has a 5\% significant block exogeneity Wald Test causality. 
Table 10: Pairwise Granger Causality and Block Exogeneity Wald Test

\begin{tabular}{|c|c|c|c|c|c|c|c|}
\hline \multicolumn{3}{|c|}{$\begin{array}{c}(1) \\
\text { Pairwise Granger Causality Test } \\
\text { (F-statistic) }-(\text { From } 19 \text { Obs })\end{array}$} & \multicolumn{5}{|c|}{$\begin{array}{c}(2) \\
\text { VAR Granger Causality Test/Block Exogeneity } \\
\text { Wald Test - Included Observations: } 19\end{array}$} \\
\hline \multirow{3}{*}{$\begin{array}{l}\text { Key: } \rightarrow " \text { does not } \\
\text { Granger Cause" }\end{array}$} & \multirow[t]{3}{*}{ F-Statistic } & \multirow[t]{3}{*}{ Prob. } & \multirow[t]{6}{*}{1.} & \multicolumn{4}{|c|}{ Dependent Variable: DLOG(X1) } \\
\hline & & & & Excluded & Chi-sq & d.f. & Prob. \\
\hline & & & & LOG(X2) & 1.894472 & 2 & 0.3878 \\
\hline $\operatorname{DLOG}(\mathrm{X} 3) \rightarrow \operatorname{DLOG}(\mathrm{X} 1)$ & 0.40076 & 0.6773 & & $\operatorname{DLOG}(\mathrm{X} 3)$ & 0.545172 & 2 & 0.7614 \\
\hline \multirow[t]{2}{*}{$\operatorname{DLOG}(\mathrm{X} 1) \rightarrow \operatorname{DLOG}(\mathrm{X} 3)$} & \multirow[t]{2}{*}{0.37152} & \multirow[t]{2}{*}{0.6963} & & $\operatorname{DLOG}(\mathrm{X} 4)$ & 2.118169 & 2 & 0.3468 \\
\hline & & & & \multirow[t]{2}{*}{ All } & \multirow[t]{2}{*}{6.286625} & \multirow[t]{2}{*}{6} & \multirow[t]{2}{*}{0.3919} \\
\hline \multirow{3}{*}{$\begin{array}{l}\text { DLOG(X4) } \rightarrow \text { DLOG(X1) } \\
\text { DLOG(X1) } \rightarrow \text { DLOG(X4) }\end{array}$} & \multirow{3}{*}{$\begin{array}{l}1.96634 \\
0.3156\end{array}$} & \multirow{3}{*}{$\begin{array}{l}0.1768 \\
0.9690\end{array}$} & & & & & \\
\hline & & & \multirow[t]{4}{*}{2.} & \multicolumn{4}{|c|}{ Dependent Variable: DLOG(X2) } \\
\hline & & & & \multirow{2}{*}{$\begin{array}{l}\text { LOG(X1) } \\
\text { DLOG(X3) } \\
\text { DLOG(X4) }\end{array}$} & 6.000922 & 2 & 0.0498 \\
\hline \multirow{2}{*}{$\begin{array}{l}\operatorname{DLOG}(\mathrm{X} 2) \rightarrow \operatorname{DLOG}(\mathrm{X} 1) \\
\operatorname{DLOG}(\mathrm{X} 1)\end{array}$} & \multirow{2}{*}{$\begin{array}{l}2.10429 \\
4.68328\end{array}$} & \multirow{2}{*}{$\begin{array}{l}0.1588 \\
\mathbf{0 . 0 2 7 7}\end{array}$} & & & $\begin{array}{l}0.087115 \\
2.840405\end{array}$ & $\begin{array}{l}2 \\
2\end{array}$ & $\begin{array}{l}0.9574 \\
0.2417\end{array}$ \\
\hline & & & & All & 13.59351 & 6 & 0.0345 \\
\hline \multirow{3}{*}{$\begin{array}{l}\text { DLOG(X4) } \rightarrow \text { DLOG(X3) } \\
\operatorname{DLOG}(X 3) \rightarrow \operatorname{DLOG}(X 4)\end{array}$} & \multirow{3}{*}{$\begin{array}{l}2.09727 \\
2.85447\end{array}$} & \multirow{3}{*}{$\begin{array}{l}0.1597 \\
0.0913\end{array}$} & \multirow[t]{5}{*}{3.} & \multicolumn{4}{|c|}{ Dependent Variable: DLOG(X3) } \\
\hline & & & & \multirow{3}{*}{$\begin{array}{c}\text { LOG(X1) } \\
\text { DLOG(X2) } \\
\text { DLOG(X4) }\end{array}$} & 1.396269 & 2 & 0.4975 \\
\hline & & & & & 1.254877 & 2 & 0.5340 \\
\hline \multirow{3}{*}{$\begin{array}{l}\text { DLOG(X2) } \rightarrow \text { DLOG(X3) } \\
\text { DLOG(X3) } \rightarrow \text { DLOG(X2) }\end{array}$} & \multirow{3}{*}{$\begin{array}{l}0.20057 \\
0.36776\end{array}$} & \multirow{3}{*}{$\begin{array}{l}0.8206 \\
0.6988\end{array}$} & & & 0.866391 & 2 & 0.6484 \\
\hline & & & & All & 4.877583 & 6 & 0.5596 \\
\hline & & & \multirow[t]{5}{*}{4.} & \multicolumn{4}{|c|}{ Dependent Variable: DLOG(X4) } \\
\hline $\mathrm{DLOG}(\mathrm{X} 2) \rightarrow \mathrm{DLOG}(\mathrm{X} 4)$ & 0.08815 & 0.9161 & & & 0.2998520 . & 2 & 0.8608 \\
\hline DLOG $(X 4) \rightarrow$ DLOG(X2) & 2.60809 & 0.1090 & & $\operatorname{DLOG}(\mathrm{X} 2)$ & 1656095.7 & 2 & 0.9205 \\
\hline & & & & DLOG(X3) & 48686 & 2 & 0.0565 \\
\hline & & & & All & 7.359665 & 6 & 0.2889 \\
\hline
\end{tabular}

\subsubsection{Variance Decomposition of the Forecast Error}

Variance decomposition of the forecast error measures the impact of the dependent variable in the form of unit shock, coming from other endogenous variables. It's measured in the percentage of unexplained error variation in the other endogenous variables. In this analysis, this is a forecast in the ARDL equations estimated beyond the time-series data period up to five years. The order is real GDP (X1), public investment (X2), private domestic investment (X3), and public-private partnership investment (X4) which is important for variance decomposition of forecast error. Table 11 gives the findings of variance decomposition of forecast error. The main objective of the variance decomposition is to provide a measure of endogeneity and exogeneity influence of the dependent variable onto the other variables and itself. This is measurable in terms of short-run and long-run.

1. Real GDP (X1) on itself explains the variation of $100 \%$ in the short-run (12 years) which reduces to about $71.20 \%$ in the fifth year. This means it had a very strong endogenous effect on itself. Real GDP (X1) on public investments (X2), private domestic investments (X3), and public-private partnership (X4) in the first year shows no response on unexplained contribution. In the succeeding 
year a 5.25\% on private domestic investments (X3) and barely on public investments at $0.16 \%$ and public-private partnership (X4) of $0.18 \%$. Taking the 4th and 5th years, public-private partnership investment responds more to real GDP at $18.03 \%$ compared to private domestic investments and public investments that follow with a slow rise to $8.12 \%$ and stable $3.09 \%$ respectively.

Table 11: Variance decomposition of forecast error

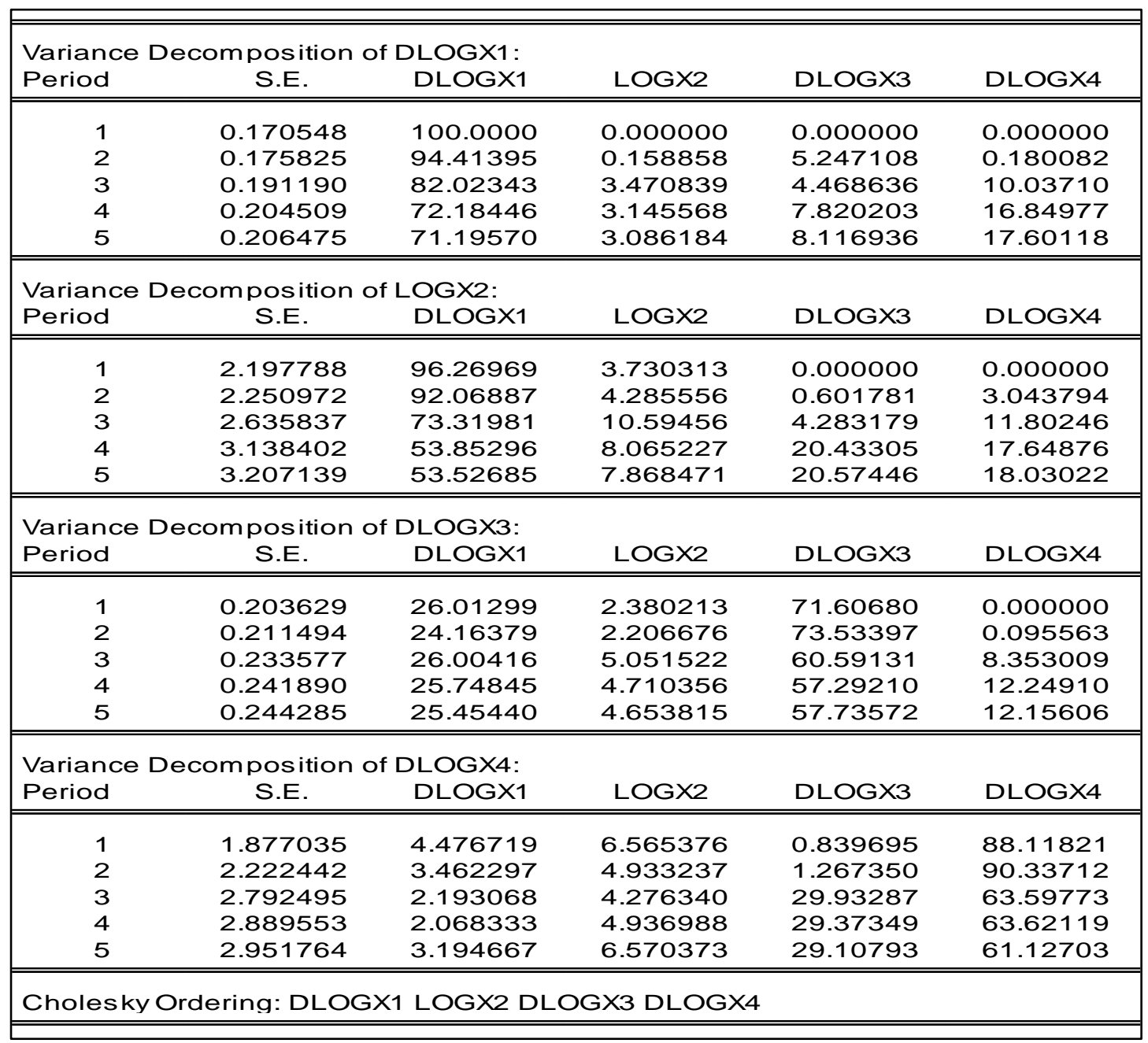

2. Public Investments (X2) shows a small contribution of unexplained errors of $3.73 \%$ and $4.29 \%$ from itself within the first and second years as short-run. This means a weak endogenous effect on itself but a strong exogenous effect, especially with real GDP. This further increases to $10.59 \%$ before declining to $8.07 \%$ and $7.87 \%$ by the fifth year in the long-run. This trend is the lowest compared to its contribution to real GDP (X1), domestic investments (X3), and public-private partnership investment (X4). However, contribution to real GDP (X1) is highest from the first year at $96.27 \%$ declining down to $53.53 \%$ by the 
fifth year. The trend shows in the private domestic investments (X3) and publicprivate partnership investment (X4) as slowly increasing where the contribution starts with zero but thereafter increases to $20.57 \%$ and $18.03 \%$ respectively. Private domestic investments register higher from the 4th and 5th years as compared to the public-private partnership investment, which tends to increase steadily.

3. Private Domestic Investments (X3) shows the contribution to itself falling from $71.60 \%$ in the first year steadily and moderately to $57.74 \%$ by the fifth year. This means it also has a strong endogenous effect on itself. There is a small margin increase in contribution to unexplained errors for public investment (X2) starting from $2.38 \%$ to $4.65 \%$ and has the least contribution to unexplained errors to forecast error among the variables. Real GDP (X1) in the first year shows the highest contribution among the variables at $26.01 \%$ and marginally declining to $25.45 \%$. However, for public-private partnerships (X4), there is zero contribution of forecast error in the first year but steadily increases up-to $12.16 \%$ by the fifth period coming second to real GDP (X1) at $25.45 \%$.

4. Public-private partnership investments (X4), to itself, contributes to forecasting error at $88.12 \%$ in the first year declining to $61.12 \%$ by the fifth year. This means a strong endogenous effect on itself. Private domestic investment (X3) barely affected in the first 2 years $(0.840 \%$ and $1.23 \%)$ but significantly rises to between $29.93 \%, 29.37 \%$, and $29.10 \%$ in the last three years of the long-term period. Public investments (X2) show $6.57 \%$ in the first year which declines slightly to the lowest $4.27 \%$ in the third year but swings back to $6.57 \%$ by the fifth year. Real GDP (X1) shows a forecast error of $4.48 \%$ within the first year which declines down to $2.07 \%$ by the fourth year and then an about-turn to $3.19 \%$ by the fifth year.

\subsubsection{Impulse Response Function}

The impulse response function is a reaction plot of an endogenous variance to one of the innovations (Shocks) above a positive or below the steady-state over a period. The graphs in Figure 2 show a plot of the behavior of real GDP (X1), public investments (X2), private domestic investment (X3), and public-private investment (X4) response to various shocks in that order. The dependent variables are rows in the order of Real GDP (X1), Public Investment (X2), Private Domestic Investment (X3), and Public-Private Partnership Investment (X4) while graphs in the row are the response of the specific shock over time. 


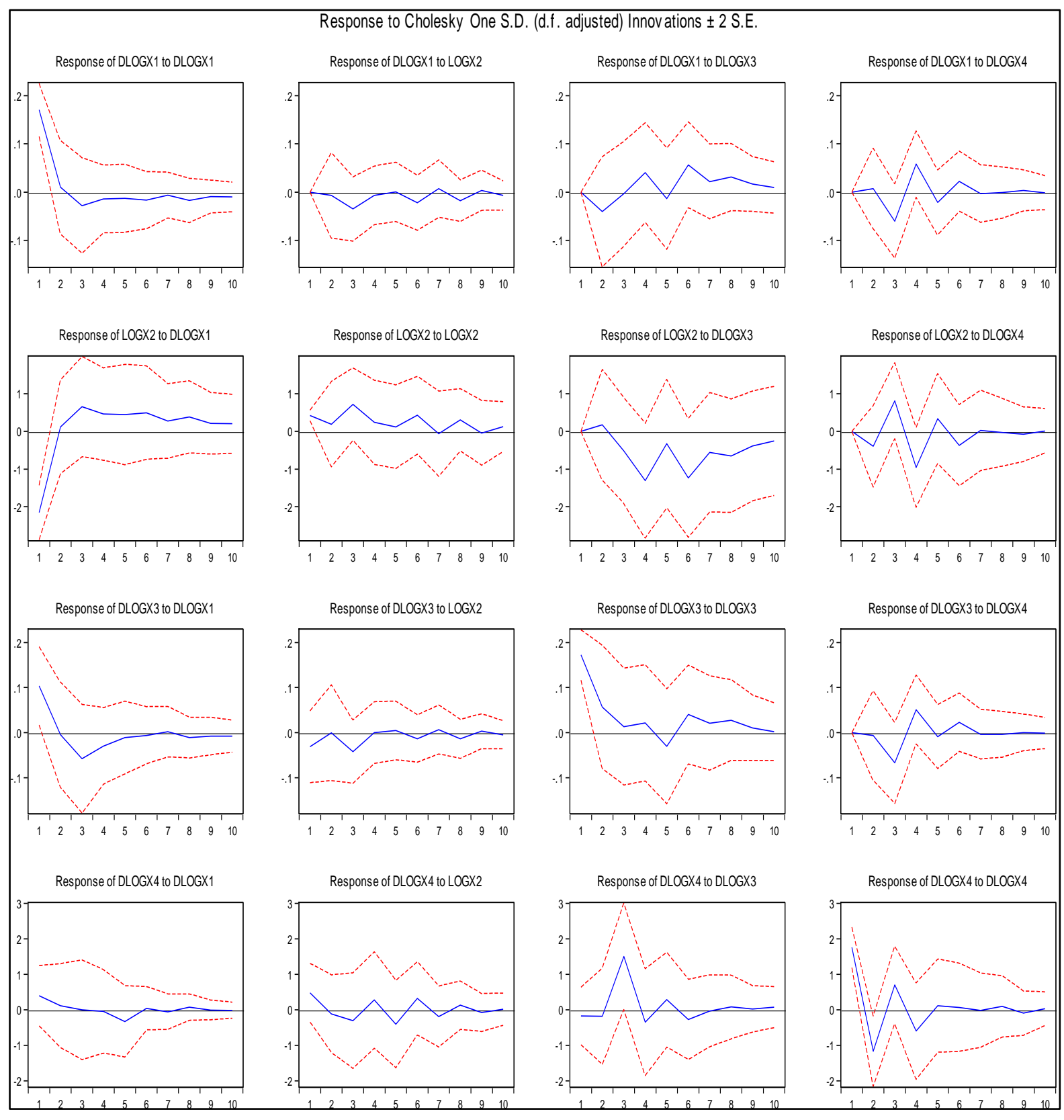

Figure 2: Impulse Response Function Graphs

1. Response on Real GDP (X1): - Real GDP(X1) response to lagged Real GDP (X1) declines from positive to slightly negative side of the steady-state level. Then stabilizes slightly below the steady-state for the rest of the entire period. Real GDP (X1) response to Public investment (X2) shock starts by fluctuating below the steady level to the 3rd period and thereafter stabilizes throughout while on the negative side. From a shock from private domestic investment (X3), real GDP (X1) declines in the first two periods below the negative side of 
the steady-state before rising above the steady (positive) state. Thereafter maintains above the steady-state though fluctuating before showing stability along with the steady-state. Real GDP response from public-private partnership investment (X4) remains (no effect) at steady state in the first 2 periods, declines to negative into the third period, before it shoots above the steady-state and then stabilizes along the steady-state.

2. Response on Public Investment (X2): - Public investments (X2) response to a shock of real GDP $(\mathrm{X} 1)$ results in a positive rise from negative to 3rd period above the steady-state. Thereafter, tapering towards a steady level into the longrun. Public investments (X2) response to its shock presents a stable wave within the positive side throughout the period. However, response to private domestic investments (X3) shock to public investments (X2) remains below the steadystate with fluctuating behavior but never gets to the positive side. The response of public investments (X4) oscillates positively and negatively before stabilizing along with the steady-state level in the long-run.

3. Response on Private Domestic Investment (X3): - Private domestic investment (X3) response from real GDP (X1) shock shows a decline from positive to negative in the steady-state to the third period. Before rising steadily and stabilizing below the steady level in the long term. Response from public investments (X2) shock shows oscillation below the steady-state level from the negative side up-to-the 4th period before stabilizing just below the steady level while on the negative side in the long-run. Response from itself (Private domestic investment (X3)) shows a steep decline to the 3rd and 4th periods. Then slumps below the steady level up-to the 5 th period before rising positively above steady-state. Thereafter, stabilizing just above steady-state in the longrun. Response from public-private partnership investment (X4) shock shows no effect up-to-the 2 nd period and then slumps to the negative side of the steadystate in the third period. This is before rising above the positive side of steadystate and thereafter stabilizing along with a steady level.

Response on Public-Private Partnership Investment (X4): - The response of publicprivate partnership investment from real GDP (X1) shock shows a slight decline along at the steady level up to the 6th period from positive to negative. This is before stabilizing along at the steady-state in the long-run. Response from public investment (X2) shock shows a decline in the first 3 periods as it oscillates along with the steady level thereafter to the sixth period. This is before stabilizing along at the steady level there around the 7 th period. Response from private domestic investment (X3) shock shows a slightly negative effect below the steady level in the first 2 periods, rises sharply to the third period, slumping back to below the steady level (negative). Then, thereafter, it stabilizes along at a steady level. On its own (public-private partnership investment (X4)) shock, there's an immediate sharp slump from positive to negative in the first period, rises sharply above steady-state level to 3rd period, before stabilizing thereafter slowly along at the steady-state level. 


\subsection{Research Findings Discussion \\ 4.3.1 Analysis of Preparation}

The time-series data showed that Kenya at some points between the years 1996 to 2017 registered negative values in public investments and real interest rates out of the trend. In the case of public-private partnership investment, there were missing data for some years, therefore, doing interpolation. The tests on stationarity, getting optimal lag, and co-integration tests informed the model of regression came before regression equations estimation. Results for the stationarity test showed except for public investments all the other time-series data were I (1); while public investment was I (0). Optimal lag using AIC showed one lag as the optimal lag appropriate for the regression model. With the time-series stationarity test indicating I (0) and I (1) integration order, the ARDL bounds test for co-integration was the preferred cointegration test. The bounds testing showed three of the equations as co-integrated with public-private partnership investment showing no co-integration. This section discusses the findings in the previous section grouped by objectives, underlying theories, and empirical studies supporting the study.

\subsubsection{Nexus between public investment and economic growth}

Public investments relate to the public interest (Pan, 2016). The public interest is on the social discount rate (Warusawitharana, 2014) that reflects society's relative valuation of the current well-being versus the future (Zhuang et al., 2007). The first note is a reduced effect of public investment impact from its own lagged values. The nexus between public investment and economic growth has a significant negative constant coefficient of -191.893 , its lag, private domestic, and publicprivate partnership investment. This significant and big negative constantcoefficient shows a strong relationship between dependent and independent variables (Gassoumis,2012) as the Granger causality showed. With only lagged real GDP as the only regressor with a positive and very significant impact too. Where 21.529 units of lagged real GDP increase accounted for a unit change of public investment. However, a reduction of 7.256 units of private domestic investment resulted in a unit increase of public investment which implies that public investment crowds out private investment that is consistent with Saidjada and Jahan (2018), Xu and Yan (2014). The results also show a reduction in the country risk premium on lending (which is desirable) though not statistically significant at 5\% but near 10\% thus having a profound effect on investment. The results also show a positive coefficient though not significant in real interest rates attributed to the positive influence of real GDP. The speed of adjustment to equilibrium is about 29.04\%. On Granger causality, real GDP Granger causes public investment. However, the level of real GDP, private domestic investments, and public-private investments as a block together cause Granger causality on public investments.

The variance decomposition of forecast error from the public investment innovation shows there exist direct and indirect transmission channels that influence economic growth (Javid, 2015). This is from judging from unexplained errors in the other 
investments short-term and long-term trends. Where in this case, the contribution of the unexplained error to the other variables by percentage is in the order of real GDP, followed by private domestic investment and then public-private partnership investment in the long-run. On public investment shocks, except private domestic investments that make impulse response to be below the steady-state level, others (real GDP, itself, and public-private investments) enhance stability above the steady-state. The implication is that public investment nexus on economic growth (real GDP) acts as a great influencer and contributor to real GDP even though with crowding-out effects on domestic private investment and public-private partnership investment. Public investment increases from a negative coefficient of the country risk premium on lending and a positive coefficient of real interest rates.

\subsubsection{Nexus between private domestic investment and economic growth}

On the nexus between private domestic investment and economic growth, the findings showed that lagged private domestic investment had a statistically very significant influence from its own lagged value and public investment. Real GDP, Public-Private Partnership investments, short-term treasury bonds, and the country risk premium on lending had a slight significant influence on private domestic investment. With ceteris paribus, an increase of real GDP (0.214) would increase a unit of private domestic investment which implies induced investment demand consistent with (Ames et al.,n.d.). An increase in public investments (0.069) would result in a unit of private domestic investment that does not have a crowding-out effect. A 0.768 contribution of its own lagged private domestic investment results in a unit increase in private domestic investment. Short term treasury bonds have a positive less significant influence on private domestic investment. This coming from the effect of loanable funds availability that is consistent with Lidiema (2017), and Olweny and Chiluwe (2012) finding on the effect of domestic debt from borrowing in the capital market. Though insignificant at 5\%, short-term treasury bill rates and the country risk premium on lending register slight significance that can be of interest to private domestic investment. However, public-private partnership investment is also less significant. Adjustment to the equilibrium shows an adjustment of $79.42 \%$ towards a steady level that is insignificant at $20.98 \%$. No Granger causality on the other endogenous variables.

Variance decomposition of forecast error on itself $(71.61 \%$ to $57.74 \%)$ is the most predominant followed by a stable real GDP $(26.01 \%$ to $25.45 \%)$ of unexplained in the error term. A marginal increase in public investments $(2.38 \%$ to $4.65 \%)$ in the short-run to the long-run, then a rising public-private partnership investment $(0 \%$ to $12.15 \%)$. This is consistent with Javid's (2015) indirect and direct transmission channels argument for economic growth. Though the forecast of unexplained errors onto itself and real GDP in the long-run have rising effects on public-private partnership investment increases. The response of shocks from Real GDP, public investments, and public-private investments stabilize along at the steady-state level after the fourth year period. The reason the private domestic investment remains on 
the negative side of the steady-state, volatility as a contributor experienced throughout over the period could suffice as stated (Pettinger, 2016; Ramey and Ramey, 1995; Ames et al., n.d.). The implication of private domestic investment as a significant contributor to economic growth; depends significantly from real GDP, public investments, and the level of short-term treasury bonds; though with a long adjustment period to equilibrium; and the slight crowding effect that retains its response below the steady level.

\subsubsection{Nexus between public-private partnership investment and economic growth.}

The assessment of the nexus between public-private partnership investment and economic growth was such that private domestic investment and short-term treasury bonds rate were the only significant at $5 \%$. This is consistent with the findings of Jasiukevicius and Vasiliauskaite (2013) on public-private partnership investments in EU countries. Private investors in investment decisions consider the time value of money and risk (Sharpe, 1964) before deciding to invest or not. This reflects the importance that private investors' inference on these two before their decisions to invest. However, lagged public-private partnership investment and public investment are insignificant contributors to public-private partnership investment. Finally, Granger causality responsiveness, though not significant at 5\%; Granger causality to real GDP at $17 \%$; private domestic investment at $15 \%$; and public investment at $10 \%$ for public-private partnership investment at pairwise causality seems strong to the others from the comparison. It also comes second after public investment in Block exogeneity on Granger causality.

On variance decomposition of forecast error, apart from itself, that has the highest unexplained forecast error contribution, an only private domestic investment that rises from $0.84 \%$ to $29.11 \%$ in the long-run. The public investment shows steadiness at $6.5 \%$ and real GDP a marginal drop from $4.48 \%$ to $3.19 \%$ in the long-run. According to the finding, it shows having the least contribution to real GDP in the long-run. This finding is consistent with reasons given by Sarmento and Oliveira (2018) on high discount values, Song et al. (2018) on payback prices, and Zangoueinezhad and Azar (2014) that could apply to Kenya. The response over the period shows stability along at a steady-state level for real GDP and public investments. While it shows being unstable in the short-run for private domestic investments. The implication is that public-private partnership investment has an insignificant contribution to real GDP, except private domestic investment and at the same time treasury bills.

\subsubsection{Internal investments and economic growth (Real GDP)}

The focus of the study is to determine the nexus between internal investments and economic growth, and the objective coming last in the list of specific objectives. The previous subsections explored the findings on the relationship among the internal investments and economic growth as the dependent variables. To 
examine the nexus, real GDP as one of the endogenous variables, its lag value is important on the influence it has on the other endogenous variables when they are dependent. The ARDL co-integration bounds test on real GDP found it was cointegrated. Meaning, a short-run and long-run equation estimation based on the error correction term as required. The co-integration test result and findings showed consistently in those countries with higher investment/GDP ratio lead to higher economic growth (UNCTAD, 2010; Anwar \& Sampath, 1999) through direct and indirect channels across investments (Javid, 2015). Findings showing the significance level contribution to internal investments from a positive lagged real GDP throughout. Real GDP on variance decomposition of forecast error also showed the highest contribution to itself on unexplained errors then followed by public-private partnership investment. Then private domestic investment and finally public investment in that order. This means lagged real GDP as having an impact in the long-run for all other investment variables on a propensity for economic growth basis. Shocks of internal investments to real GDP helps it maintain the real GDP effect maintained at along the steady-state level in the long-run. Except for public investment that rises from the negative side and maintained positively above the steady-state for real GDP. This means real GDP growth sustained itself above the steady-state level coming from the other internal investments in fueling economic growth.

The regression estimates for Economic growth (Real GDP) shows a positive and strong statistically significant influence from lag values of its own, public investment, and private domestic investment except for public-private partnership investment that was less significant and negative. Commercial banks' lending interest rate and the country risk premium on lending findings exhibit a significant influence on real GDP at a $10 \%$ significance level. The country risk premium is a function of commercial banks lending rate and risk-free interest rate (used shortterm treasury bills) hence the effect. Regarding public investment, its significance attributes are consistent with Arrow et al. (2013) and Zhuang et al. (2007) on the rate of return and time preference composite for real GDP growth. The error correction adjustment towards equilibrium is $28.29 \%$. On Granger causality, real GDP does cause Granger causality to public investments. Real GDP with private domestic investments and public-private partnership investment as a block jointly cause Granger causality to public investments.

Real GDP shock explained by variance decomposition of error term has no impact on error terms of public investment, private domestic investment, and public-private partnership investment in the first year due to its strong endogeneity. All 100\% going to itself in the first period. In the long-run, 1) apart from real GDP that declines to $71.20 \%$; 2) public investments increase to $3.08 \%$; 3) private domestic investments increases to $8.12 \%$, and 4) public-private partnership investment increases with the highest impact to $17.60 \%$ in the long-run. The impulse response function from real GDP to itself shows a decline in real GDP in the short-run below the steady-state, while public investments make oscillate below the steady-state over the entire period projected. The lagged values of private domestic and public- 
private partnership investment results in real GDP oscillating above and below the steady-state up-to-the sixth period before stabilizing along at the steady-state.

\section{Summary, Conclusions, and Recommendations}

The purpose of this causality research study was to determine the nexus between internal investments and economic growth. Such that, the findings of the study would be to supplement existing knowledge on the importance of internal investments and economic growth to sustain a $10 \%$ economic growth required by the specified vision. Where the knowledge about the linkages between the two would be of help in decisions that could achieve envisioned growth by the year 2030 . Time-series trends of these internal investments (public investments, private domestic investments, and public-private partnership investment), real GDP and discounting rates informs the context of analysis. Specifically, the influence of a) the real interest rate that is associated with real GDP rather than nominal GDP. b) The public investments that are associated with the short-term treasury bill rates to represent the social discount rate. c) The private domestic investment that is associated with commercial banks lending interest rate. d) The public-private partnership investment is associated with country risk premium on lending. The significance, causality, forecasting, and impulse response to shocks of these variables form the interest basis of this study to infer the linkages.

The study on the linkages between investment and economic theories responds to specific objectives of a) determine the nexus between public investment and economic growth; b) establish the nexus between private domestic investment and economic growth; c) assess the nexus between public-private partnership investment and economic growth; and d) examine the combined nexus between internal investments and economic growth in Kenya.

\subsection{Summary}

Before getting on with the analysis, stationarity tests directed the use of ARDL bounds co-integration tests rather than Johansen co-integration test, since public investment time series data was I (0) while the rest were at I (1). The optimal lag was determined to be I (1). The co-integration bounds testing finding was such that three of the equations were co-integrated hence requiring estimation of error correction term. It is from regression estimates that inference required for the impact significance of lagged values of real GDP, public investment, private domestic investment, and public-private partnership investment and their discounting rates were determined. Investment discounting rates in this case being real interest rates, treasury bills rate, commercial lending interest rate, and the country risk premium on lending. The other interest in the nexus interest is whether variables had Granger causality at pairwise and as a block-level, (Wald Test) levels. Variance decomposition of forecast error and impulse response function conclude analysis on investment's impact in the short-run and the long run. 


\subsubsection{Public Investment and Economic Growth}

Public investment had a strong and statistically significant influence from lagged real GDP, public investment, and private domestic investment at a 5\% significance. The exception was only public-private partnership investment. This means that public investment is a key player in economic growth even though the impact of public-private partnership investment $(87.60 \%)$ were insignificant. The indifference according to the findings showed that apart from real GDP which shows a positive coefficient, it has a negative coefficient relationship influence by its own lagged value, private domestic investments, and public-private partnership. It was also notable that real interest rates and the country risk premium on lending had some influence though not significant. It has a very significant influence on real GDP at $2.98 \%$ well below $5 \%$ significant level. This is besides a strong influence too on private domestic investment at $2.29 \%$. It also shows a $29.04 \%$ short-term shocks adjustment to equilibrium even though insignificant. On forecasting, its effect, in the end, shows a strong presence in the order of real GDP, private domestic investment, and public-private partnership.

The findings reject the null hypothesis that public investments do not influence economic growth. Relating to the time preference theory of interest rates, real interest rates, and the country risk premium on lending have an impact as exogenous variables, though not very significant. Saidjada \& Jahan (2018), in Bangladesh, found public investment had crowding effects, as is the case for Kenya. Even though findings show crowding-out effects for private domestic investments, public investments have a significant impact on private domestic investments. Comparing the contribution of public investment and private domestic to real GDP, findings are comparable to Japan rather than the USA where private domestic investment contributes more. The findings conclusion is that the impact of public investments in the long-run was in real GDP, private domestic investment, and public-private partnership investment with little effect for all in the short-run.

\subsubsection{Private Domestic Investment and Economic Growth}

Private domestic investment findings show its strongest influence coming from its own lagged value and public investment. It also registers less significant impact from lagged real GDP, public-private partnership investment, short-term treasury bills rate, and the country risk premium on lending. The real interest rate is the least significant. On the other hand, private domestic investment has a very strong statistically significant impact on real GDP, public investment, itself, and publicprivate investment. This is despite the significant negative coefficient impact on public investment. Regarding adjustment to short-run shocks, responsive to adjustment to equilibrium finding is about $79.42 \%$ with a less significance rate of about 0.20 the highest among the other co-integrating series of investment and real GDP. On Granger causality, it is only public-private partnership investment that private domestic investment has near significance. On the variance for forecast error, private domestic investment contributes a steady impact on real GDP distributed 
within a small margin of around $25 \%$ in the short-run and the long-run. The findings reject the null hypothesis that private domestic investments have no relationship with economic growth in Kenya. The loanable funds' theory advances the availability of loanable funds; relationship finding shows that treasury bills rate and the country risk premium on lending ha significance at $22.31 \%$ and $23.10 \%$ respectively which were way above the threshold of about $5 \%$ or $10 \%$ significance level; and real interest rates even worse at $51.48 \%$. In a related study by Lidiema (2017) in Kenya, there was some consistency in the effects of domestic investments. Domestic savings used as the proxy for domestic investments do show the shortterm and long-term dynamic relationship with economic growth as one of the variables (Olweny and Chiluwe, 2012; Emmanuel and Kehinde, 2018). On crowding effects, Makuyana and Odhiambo (2018) case in Malawi was consistent with the findings in Kenya. In comparison with public investments, public-private partnership investments, and real GDP, on response function private domestic investment has the best propensity to remain within the steady-state in the long-run their shocks.

\subsubsection{Public-Private Partnership Investment and Economic Growth}

Public-private partnership investment analysis is based on time-series data that had missing values in some years where there was interpolation to fill the missing years, meaning this could make better or worse the findings. The finding gave private domestic investment a strong positive significant influence together with the treasury bills rate. Real GDP also showed less significance and the real interest rate at $13.45 \%$ and $15.91 \%$ not far below $10 \%$ significance. Short-term treasury bonds have a significant influence on private domestic investments and public-private partnership investment. However, lagged public-private partnerships, public investment, and commercial banks lending interest rates were insignificant. Regarding its impact on other investment and real GDP, it has a negative coefficient for a positive impact on real GDP and public investment. However, insignificance from public investment and real GDP. It also has slight significance but positive for private domestic investments. On variance decomposition on error terms, from the short-run to the long term, the impact of private domestic investment on real GDP is moderate at around 25\% remaining constant, little on public investment but steadily increasing in public-private partnership investment. Most of the unexplained errors in the forecast are from itself.

The findings on public-private partnership investment accepted the hypothesis that public-private partnership investment has no relationship with economic growth. This was from a statistical significance of $p=0.1970$ that is way above either .05 or 0.10 significance. Asset pricing theory based on the time value of money and risk principles plays an important role in public investment consideration by private investors. It is from this basis that the difference between treasury bills rate (social discount rate) and real interest rates explain the risk factor involved in investor decision. Sarmento and Oliveira (2018) argue due to most public-private 
partnership investments applying debt to finance over $80 \%$ of total investment this resulted in unrealistic discounting values and hence high leverage values. Song et al. (2019) the pricing of such projects should be between the private sector and socially optimal (about in between treasury bills rate and commercial banks lending rates). However, the significance of public-private partnership investment significance could relate to Zangoueinezhad and Azar (2014), on the number of projects underway, the value of PPPs projects, and the ideal type of contracts put in place. Even though it has the least contribution of unexplained errors in the forecast to real GDP and public investments, most of its effects for the long-run are in itself and domestic investment.

\subsubsection{Internal Investments and Economic Growth}

The study is about the nexus between internal investments and economic growth, therefore the impact of economic growth itself on each of the internal investments provides a notion of opportunity cost when there is a change in economic growth. Secondly, the impact of an increase in real GDP theoretically increases real interest rates. Therefore, looking at the impact of real interest rates first, it shows statistical significance in the order of $15.91 \%, 19.30 \%$, and $51.48 \%$ to the public-private partnership, public investments, and private domestic investments respectively. While the findings on the influence of past real GDP shows a positive and significant influence on current real GDP $(0.02 \%)$ and public investment $(0.25 \%)$ at a 5\% significance level. The influence significance of past real GDP on publicprivate partnership investment (13.45\%) and private domestic investment (22.72\%) compared to real GDP (itself) and public investment is not as significant. Real GDP as the dependent variable significantly influenced by its lag, public investment, and public domestic investment in that order.

Internal investments nexus with economic growth findings show that the lagged values of real GDP, public investment, and private domestic investment significantly influenced real GDP. While the public-private partnership is not significant i.e. over 5\% ( $>$ >.05). Commercial bank's lending interest rates and the country risk premium on lending rates are significant when you consider $10 \%$ significance. By inference, loanable funds theory (for commercial banks lending interest rates) and asset pricing theory (that takes risk premium between market risk and risk-free interest rates, implied that the time preference theory of interest rates) theories had a significant influence on real GDP based on the time-series period under consideration. Which then, real GDP according to results, causes Granger causality on public investment. In the short-run and long-run, variance decomposition of forecast error shows its biggest effect on itself with more notable in public-private partnership investment that is insignificant. With private domestic investment and public-private investment, impulse response function showed fluctuation above higher values along at the steady-state.

As shown in Figure 3, it infers the findings and the nexus between internal investments and economic growth where the ARDL model equations plot depicts a 
deteriorating situation for the next 20 years. The plot shows declining real GDP, public investment, private domestic investment, and public-private partnership investment over the next 20 years due to the significant negative constantcoefficient from public investment. The plot using the estimated values of the next 20 years assumes that static exogenous discounting value used in 2017 applies over the period i.e. 2018 to 2037. Therefore, with this high value of -191.893 negative significant coefficient does not portray a realistic situation warranting a growth of real GDP for economic growth.

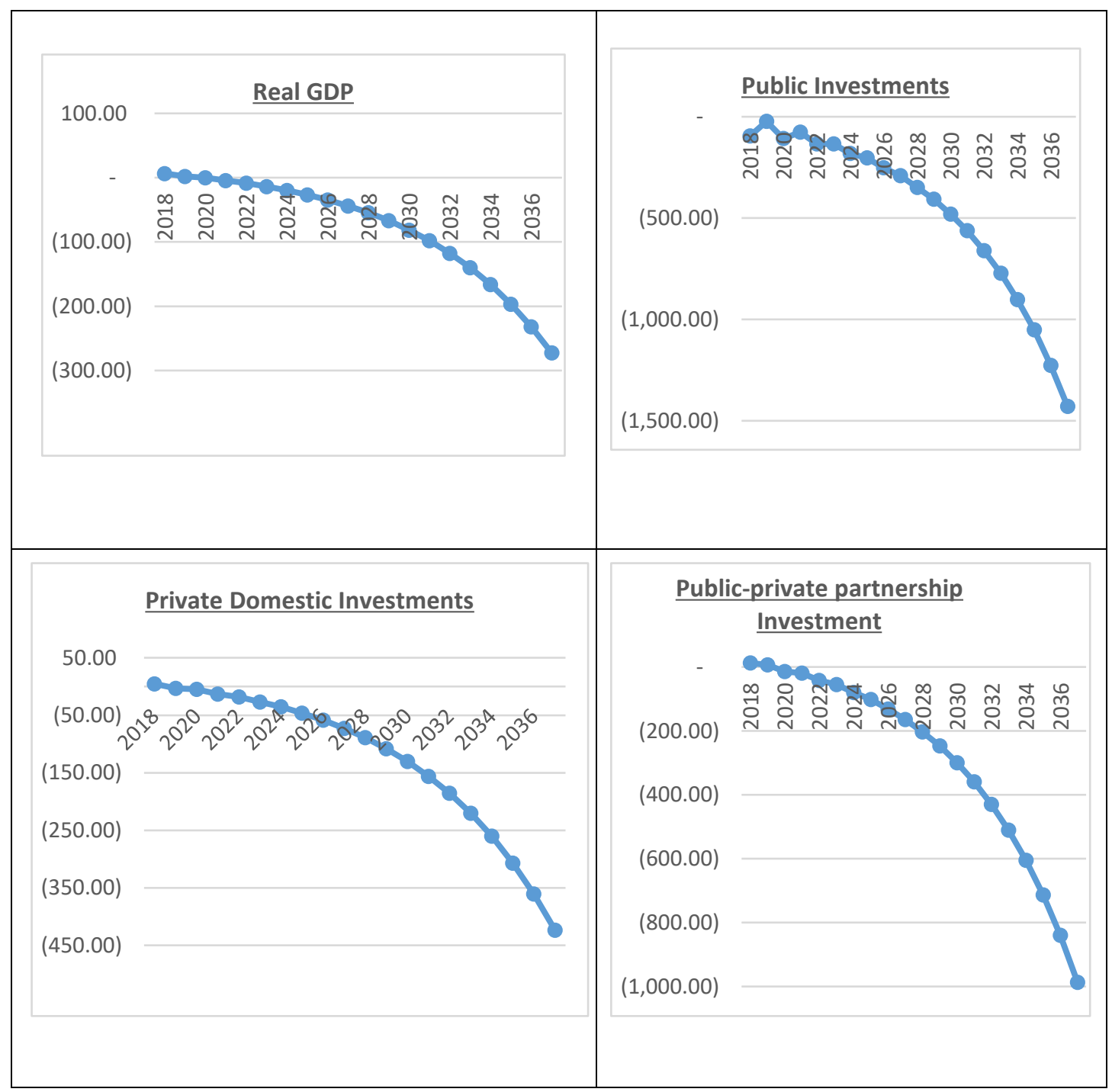

Figure 3: Projections of Endogenous Variables for the next 20 years (2018 to 2037)

Note: Figure 3 is a plot of variables incorporating an unrealistic negative significant coefficient of -191.893 and its effects. 
In Figure 4, the projection for real GDP changes to realistic values when subjected to a shift of 122 as bare minimum units to -191.893 of the public investment significant constant coefficient. The rationale is that public investment from the results is the most exogenous and has block Granger causality on all the other endogenous variables and it's the only one among the endogenous variables that have a significant constant coefficient. This reverses the declining real GDP growth and too happens to public investment, private domestic, and public-private partnership investments. Once again, this is under the assumption that static exogenous variables remain as were in the year 2017 for the next 20 years. This is like shifting up the estimation equation by 122 units on the public investment equation that would go to autonomous constant-coefficient offsetting on the basis that there still be public investment in the projected period to the year 2037, unlike the first case. This leads to reversing the real GDP growth decline in Figure 3 to increasing which is the desire to attain envisaged economic growth. Figure 4 graphs demonstrate what happens to real GDP, Public Investment, private domestic, and public-private partnership investment from an exogenous strong, Granger Causality on the other endogenous variables from public investments. 


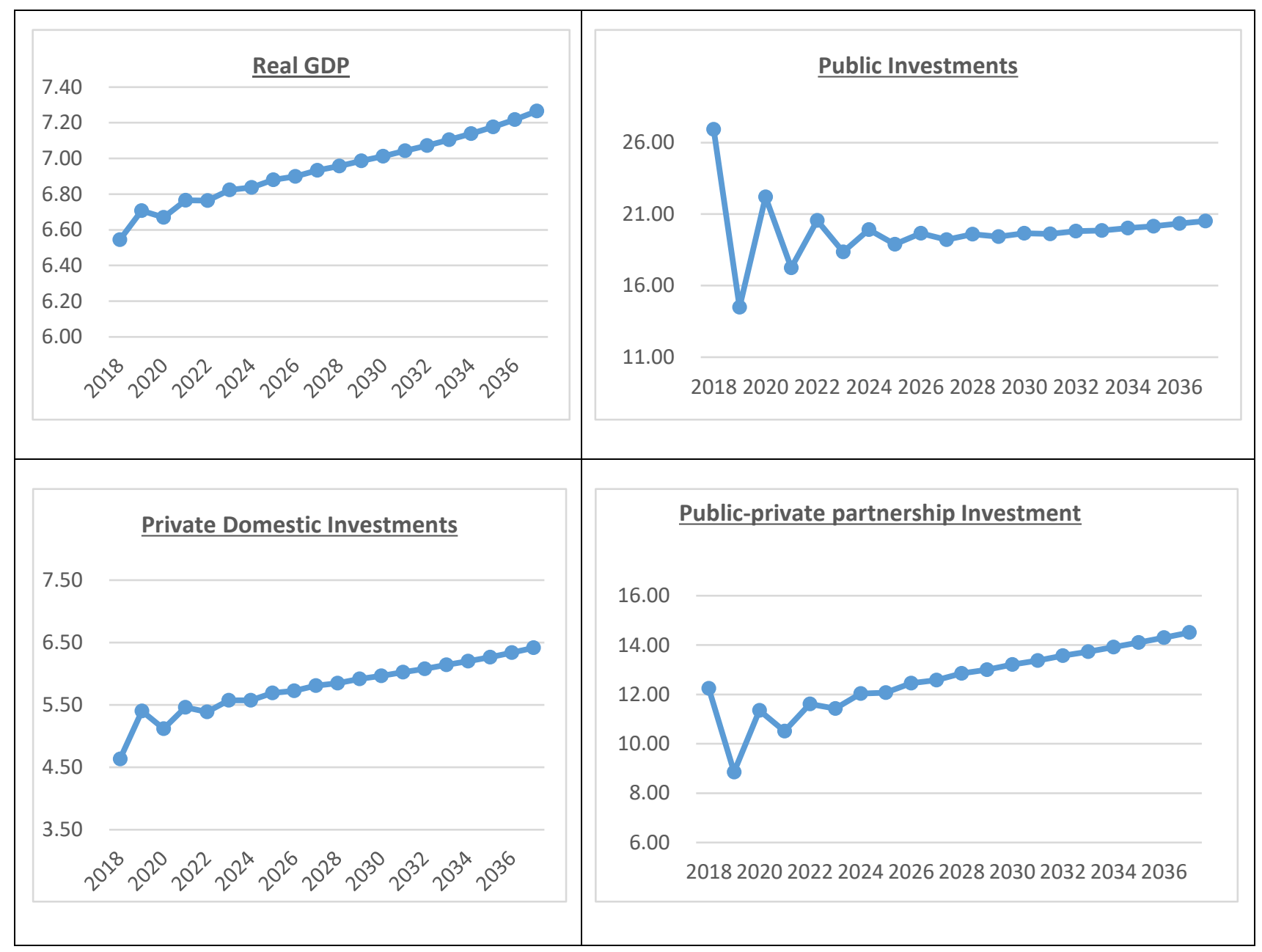

Figure 4: Realistic Real GDP Growth Projections by Intervention for the next 20 years. (2018 -2037)

Note: Vertical Axis Values in Log10, Horizontal Projection Years.

Estimated ARDL equations from an upward adjustment of 122 units on public investment significantly constant coefficient.

Basing the argument specifically for public investment, considering the real growth from a sample from European countries, according to IMF, World Economic Outlook Report (2014) an increase of percentage point of GDP in public investment spending increased the level of output by 0.4 percent in a year and by $4 \%$ by the fourth year. In this study, it gives an average of $0.44 \%$ per year and $3 \%$ by the fourth year. This means in comparison; we are below the European countries. On the other hand, for an open economy, $\mathrm{C}+\mathrm{I}+\mathrm{G}+(\mathrm{X}-\mathrm{M})$, investment is a component of national output and the study only considered part of investment related to local investments. The factors and determinants of investment relating to effective and efficient impact like efficiency gap would play a lot to affect the impact of public investment translating onto economic growth. 


\section{Conclusions}

This study was to scrutinize the nexus between internal investments and economic growth that found the time series integrated at I (0) and I (1). The ARDL bounds co-integration tests applicable in this case found that three of the equations were cointegrated. The short-run adjustment into the long-run was that private domestic investment adjusted faster than real GDP and public investment regression estimates. The findings also showed that private domestic investment had a better significance adjustment to short-run disequilibrium in the long-run in comparison to the others. This is even though private domestic investments experienced crowding-out effects from public investments, the opposite of which a positive significant impact from public investment. Over the same note, the impact significance of internal investments on real GDP, by significance at 5\%, the order was real GDP, public investment, and finally private domestic investment. The sequence arising from Granger causality shows that real GDP does Granger causality to public investment. In return, public investment has a significant Granger Causality Test/Block Exogeneity Wald Test to internal investments including real GDP. The relative impact retention into the long-run in real GDP, private domestic investment, and public-private partnership investment is high as findings showed in the variance decomposition of forecast error. This shows the importance of these endogenous variables response shocks that could affect the intended economic growth impact. This is unlike, the public investment whose shocks on errors are in real GDP, domestic investment, and public-private investment percentages in that order.

Behind investment decisions, the short-term treasury bills rate shows a significant influence as the only one at a 5\% significance level on public-private partnership investment. Then, the commercial bank lending rate and the country risk premium on lending also has a significance at $10 \%$ significance on real GDP. Though not significant, real interest rates, also show significance below $20 \%(\mathrm{p}<0.2)$ for public and public-private partnership investment and the country risk premium on public investments. Treasury bills rate and the country risk premium on lending also show less significant influence on private domestic investments at $22.31 \%$ and $23.10 \%$ significance.

\subsection{Recommendations}

Based on these findings, the nexus between internal investments and economic growth showed that by ensuring sustained economic growth in real GDP as the best option basis to achieve the desired economic growth for Kenya. On this, it should start from a sequence focusing on economic growth inclination where pairwise causality showed past real GDP does cause public investment. Then, public investment showed a significant block causality to internal investments that also include real GDP. Private domestic investment in this co-integration equation had the fastest readjustment to equilibrium when you consider the extent of the error correction term. This means the government should pay attention to sustained real 
GDP growth supported by public investments which in turn has a significant impact on private domestic, public-private partnership investment and real GDP itself.

With various interest rates applied in investment discounting; and as exogenous in this study; and with effects on internal investment decisions and volume; real interest rates, treasury bills rates, commercial banks lending interest rates, and the country risk premium on lending are important to achieving economic growth anticipation through investments they affect accordingly. As such, the significant impact to support investments from macroeconomic stability policies that reflect sustaining the strategy above for achieving economic growth could target specific investment types to achieve desired results. The fiscal and monetary stabilization policies addressing those integral factors that would influence positively starting from those with four stars $(* * * *)$, followed with three stars $(* * *)$, and so on as shown in Table 12.

Table 12: Significance of exogenous variables

\begin{tabular}{|c|c|c|c|c|}
\hline \multirow{2}{*}{$\begin{array}{l}\text { Exogenous } \\
\text { Variable }\end{array}$} & \multirow{2}{*}{$\begin{array}{l}\text { Endogenous } \\
\text { Variable }\end{array}$} & \multicolumn{2}{|c|}{ Significant } & \multirow[t]{2}{*}{ Comment } \\
\hline & & p-value & & \\
\hline \multirow[t]{3}{*}{ Real Interest Rate } & $\begin{array}{c}\text { Public-Private } \\
\text { Partnership Investment }\end{array}$ & 0.1591 & $* * *$ & Significant at $20 \%$ \\
\hline & Public Investment & 0.1930 & $* * *$ & Significant at $20 \%$ \\
\hline & $\begin{array}{c}\text { Private Domestic } \\
\text { Investment }\end{array}$ & 0.5148 & & Insignificant \\
\hline \multirow[t]{2}{*}{ Treasury Bills Rate } & $\begin{array}{c}\text { Public-private } \\
\text { partnership investment }\end{array}$ & 0.0461 & $*$ & Significant at $5 \%$ \\
\hline & $\begin{array}{l}\text { Private Domestic } \\
\text { Investment }\end{array}$ & 0.2231 & $* * * *$ & Significant at $30 \%$ \\
\hline \multirow{2}{*}{$\begin{array}{c}\text { Commercial Banks } \\
\text { Lending Interest } \\
\text { Rates }\end{array}$} & Real GDP & 0.0886 & $* *$ & Significant at $10 \%$ \\
\hline & $\begin{array}{c}\text { Public-private } \\
\text { partnership investment }\end{array}$ & 0.7206 & & Insignificant \\
\hline \multirow{3}{*}{$\begin{array}{c}\text { Country Risk } \\
\text { Premium on Lending }\end{array}$} & Real GDP & 0.0926 & $* *$ & Significant at $10 \%$ \\
\hline & Public Investment & 0.1440 & $* * *$ & Significant at $20 \%$ \\
\hline & $\begin{array}{c}\text { Private Domestic } \\
\text { Investment }\end{array}$ & 0.2310 & $* * * *$ & Significant at $30 \%$ \\
\hline
\end{tabular}

The results of this study used time-series observations over a period when there were economic, political, and social flip-flops from changes enacted within the years 1996 to 2017 in Kenya. These flip-flops provide areas of interest to researchers where effects could consider effects that are visible in structural changes in the series used. Other issues of considerable interest would be exogenous effects of declining gross domestic savings, human capital index, CPIA transparency, accountability, and corruption index in the public sector mentioned earlier. These indicators could be essential in how the linkages of internal investments could help to propel further economic growth and investment efficiency. Just like a sample of countries from advanced countries showed a percentage point increase in public 
investment of GDP spending increasing output by 0.4 percent in the first one year and 1.5 percent after 4 years, reducing the efficiency gap of $27 \%$ in investment effect on economic growth, in this case, it shows an average $0.44 \%$ annually and $3 \%$ in four years unlike in advanced countries. But in conclusion, paying attention to the above areas would make it possible to attain envisaged economic growth especially for a developing nation.

ACKNOWLEDGEMENTS. I express gratitude to corresponding author for reviewing and guidance, Dr. T. Olweny. Eviews (IHS Markit) immediate response to assist in the registration and extension of the registration period for statistical analysis application to finish the analysis of this research project during tough Covid-19 pandemic period.

\section{References}

[1] Abiad, A., Furceri, D., and Topalova, P. (2015). The Macroeconomic Effects of Public Investment: Evidence from Advanced Economies. IMF Working Paper, WP/15/95

[2] African Development Bank Group (AfDB) (2018). African Economic Outlook 2018

[3] African Development Bank Group (AfDB) (2014). Country Strategy Paper 2014-2018

[4] Akbota, A., and Baek, J. (2017). The Environmental Consequences of Growth: Empirical Evidence from the Republic of Kazakhstan, Economies, ISSN 22277099, MDPI, 6(1), pp. 1-11

[5] Ali, G. (2015). Factors affecting public investment in manufacturing sector of Pakistan. European Journal of Economimakc Studies, 13(3), pp. 122-130

[6] Ames, B., Brown, W., Devarajan, S., and Izquierdo, A. (n.d.). Chapter 12 Macroeconomic Issues http://siteresources.worldbank.org/INTPRS1/Resources/3836061205334112622/3360_chap12.pdf

[7] Anwar, M. S., and Sampath, R.K. (1999). Investment and economic growth. Department of agricultural and resource economics, Colorado State University

[8] Arrow, K., Cropper, M., Gollier, C., Groom, B., Heal, G., Newell, R., Nordhaus, W. Pindyck, R., Pizer, W., Portney, P., Sterner, T., Tol, R. S. J.M., and Weitzman, M. (2013). Determining Benefits and Costs for Future Generation. SCIENCE, pp.341, 26 JULY 2013

[9] Bakari, S. (2017). The impact of domestic investment on economic growth: new evidence from Malaysia. Munich Personal RePEc Archive. https://mpra.ub.uni-muenchen.de/79436/1/MPRA_paper_79436.pdf

[10] Emmanuel, O.E., and Kehinde, A. (2018). Domestic investment and economy Growth in Nigeria: An Empirical Investigation. International Journal of Business and Social Science, 9(2), February 
[11] Ferrer, C. E., and Zermeño, V.E. (2015). Foreign Direct Investment and Gross Domestic Product Growth. Procedia Economics and Finance. 24. pp. 198-207.

[12] Finance Circular No. 2009/02 (2009). The National Public Private Partnerships (PPP) Policy Framework and National PPP Guidelines, Department of Finance and Deregulation, Australian Government

[13] Frees, E. W. (2004). Longitudinal and panel data analysis and applications in the social sciences. New York, NY, USA: Cambridge University Press

[14] Gassoumis, Z. (2012). Re: A negative coefficient for a constant in a linear regression?.

https://www.researchgate.net/post/A_negative_coefficient_for_a_constant_in a linear_regression/50269761e24a461568000031/citation/download

[15] Ghani, E., and Din, M. (2006). The Impact of Public Investment on Economic Growth in Pakistan. The Pakistan Development Review. 45(1), pp. 87-98

[16] Gollier, C. (2014). Discounting and Growth, American Economic Review, American Economic Association, 104(5), pp. 534-537

[17] Granger, C.W.J., and Newbold, P. (1974). Spurious regressions in econometrics, Journal of Econometrics, 2 (1974), pp. 111-120.

[18] Harrison, M. (2010). Valuing the Future: the social discount rate in cost-benefit analysis, Visiting Researcher Paper, Productivity Commission, Canberra

[19] Herbener, J. M. (2011). The Pure Time-Preference Theory of Interest (edited). Ludwig von Mises Institute.

[20] International Monetary Fund (IMF), (2014). World economic outlook - the IMF and infrastructure governance. https://www.imf.org/external/np/fad/publicinvestment/index.htm

[21] Javid, M. (2019). Public and Private Infrastructure Investment and Economic Growth in Pakistan: An Aggregate and Disaggregate Analysis. Sustainability, MDPI, Open Access Journal, 11(12), pp. 1-22

[22] Jasiukevicius, L. and Vasiliauskaite, A. (2013). The relation between economic growth and public-private partnership market developmentin the countries of the European Union. Economics and Management, 18 (2)

[23] Kenya National Bureau of Statistics (KNBS) (2014). Information on the revised national accounts. https://www.knbs.or.ke/download/rebased-gdpfacts/

[24] Ketkar, S. and Ratha, D. (2009). Innovative Financing for Development, The World Bank. http://pubdocs.worldbank.org/en/335011444766662755/e-bookInnovative-Financing-for-Development.pdf

[25] Klein, M. (1997). The risk premium for evaluating public projects. Oxford Review of economic policy, 13(4)

[26] Koundouri, P. (2015). Financial and social discount rate for the assessment of government investment decisions: Why is financial and social cost benefit analysis and the corresponding social discount rate important for Moldova?

[27] Lee, K.N.H. (2012). Inflation and Residential Property Markets: A Bounds Testing Approach. International Journal of Trade, Economics and Finance, 3(3) 
[28] Lesson 6 - The Social Discount Rate (n.d.). https://cals.arizona.edu/classes/rnr485/ch6.html

[29] Lidiema, C. (2017). Effects of Government Borrowing on Private Investments in Kenya. Kenya Bankers Association. WPS/06/17

[30] Lindner, F. (2013). Does Saving Increase the Supply of Credit? A Critique of Loanable Funds Theory. Macroeconomic Policy Insitute (IMK)

[31] Maingi, J. N. (2017). The Impact of Government Expenditure on Economic Growth in Kenya: 1963-2008. Advances in Economics and Business 5(12), pp. 635-662

[32] Makuyana, G., and Odhiambo, N.M. (2.018). Public and private investment and economic growth in Malawi: an ARDL-bounds testing approach. Economic Research- Ekonomska istraživanja 32(1), pp. 673-689

[33] Mankiw, G.N. 1997. Macroeconomics, Third Edition. New York: Worth Publishers, 1997.

[34] Menegaki, A.N. (2019). The ARDL Method in the Energy-Growth Nexus Field; Best Implementation Strategies. Economies, 7(4)

[35] Moralos, D., and Amekudzi, A. (2008). The state of the practice of value for money analyses in comparing public private partnerships to traditional procurement. Public Works Management and Policy, 13(2), pp. 114-125

[36] Olweny, T., and Chiluwe, M. (2012). The Effect of Monetary Policy on Private Sector Investment in Kenya. Journal of Applied Finance \& Banking, 2(2), pp. 239-287

[37] Oukhallou, Y (2016). Analyzing Economic Growth: What Role for Public Investment? Journal of Economics Bibliography, KSP Journals, 3(1), pp. 7199

[38] Pan, L. (June 2016). The effect of public investment in stimulating private investment in China. Journal of Convergence Information Technology (JCIT), 11(3)

[39] Parker, D., and Hartley, K. (2003). Transaction costs, relational contracting and public-private partnerships: A Case Study of UK Defense. Journal of Purchasing and Supply Management

[40] Pahlavani, M., Wilson, E. and Worthington, A.C. (2005). Trade-GDP Nexus in Iran: An Application of the Autoregressive Distributed Lag (ARDL) Model. American Journal of Applied Sciences, 2 (7), pp. 1158-1165

[41] Pesaran, M. H., Shin, R. and Smith, R.J. (2001). Bounds Testing Approaches to the Analysis of Level Relationships. Journal of Applied Econometrics, 16(3), pp. 289-386

[42] Pettinger, T. (May 6, 2016). Investment and economic growth, https://www.economicshelp.org/blog/495/economics/investment-andeconomic-growth/

[43] Pimentel, I., St.Aubyn, M., and Ribeiro, N. (2016). The impact of investment in Public Private Partnerships on Public, Private investment and GDP in Portugal. Working Papers Department of Economics2017/13, ISEG - Lisbon 
School of Economics and Management, Department of Economics, Universidade de Lisboa.

[44] Rabnawaz, A., and Jafar, R.M.S. (2015). Impact of public investment on economic growth. Online athttps://mpra.ub.uni-muenchen.de/70377/, MPRA Paper No. 70377

[45] Ramey, G., and Ramey, V.A. (1995) Cross-country evidence on the link between volatility and growth. American Economic Review. 85:1138-51.

[46] Saidjada, K.M., and Jahan, S.I. (2018). Public and private investment nexus in Bangladesh: crowding-in or out?, Journal of Developing Areas, Tennessee State University, College of Business, 52(4), pp. 115-127

[47] Sarmento, J.M. (2010). Do public-private partnerships create value for money for the public sector? The Portuguese Experience. OECD Journal on Budgeting, 2010(1)

[48] Sarmento, J.M. and Oliveira, M. (2018). Use and limits in project finance of the capital asset pricing model: Overview of highway projects. EJTIR,18(4), pp. 555-568

[49] Schachter, H.L., Daniel, J., and Liu, R.R. (Jan. 2017). Win-win agreements and public private partnerships: managerial and governance concerns

[50] Sharpe, W.F. (1964). Capital Asset Prices A Theory of Market Equilibrium under Conditions of Risk, Journal of Finance, 19 (3), pp. 425-442.

[51] Sirtaine, S., Pinglo, M.E., Guasch, J.L., and Foster, V. (2005). How Profitable Are Infrastructure Concessions in Latin America? Empirical Evidence and Regulatory Implications. The World Bank.

[52] Shrestha, B., and Bhatta G. R. (2018). Selecting appropriate methodological framework for data analysis. The Journal of Finance and Data Science, 4(2), pp. 71-89.

[53] Song, J., Zhao, Y., Jin, L., and Sun, Y. (Nov. 2018). Pareto optimization of public-private partnership toll road contracts with government guarantees. Elsevier: Transportation Research Part A,117(2018), pp. 158-175

[54] Storm, S. (2017). Some thoughts on secular stagnation, loanable funds and the ZLB. https://www.ineteconomics.org/uploads/papers/Storm-Some-thoughtson-secular-stagnation-loanable-funds-and-the-ZLB6.pdf

[55] UNCTAD (2010). Partnering public and private investment for development. Trade and Development Board Investment, Enterprise and Development Commission Multi-Year Expert Meeting on Investment for Development, 3(3)

[56] UNCTAD (2018). World investment report: Investment and new industrial policies.

[57] Warsono, Russel, E., Wamiliana, Widiarti, and Usman, M. (2019). Vector Autoregressive with Exogenous Variable Model and its Application in Modeling and Forecasting Energy Data: Case Study of PTBA and HRUM Energy. International Journal of Energy Economics and Policy

[58] Warusawitharana, M. (2014). The Social Discount Rate in Developing Countries. FEDS Notes. 
https://www.federalreserve.gov/econresdata/notes/feds-notes/2014/the-socialdiscount-rate-in-developing-countries-20141009.html

[59] Wehinger, G. (2011). Fostering long-term investment and economic growth Summary of a high-level OECD financial roundtable. OECD Journal: Financial Market Trends, 2011(1)

[60] World Bank, (April 05, 2018). Infrastructure and public-private partnerships

[61] Xu, X., and Yan, Y. (2014). Does government investment crowd out private investment in China? Journal of Economic Policy Reform, 17(1), pp. 1-12

[62] Zangoueinezhad, A., and Azar, A. (2014). How public-private partnership projects impact infrastructure industry for economic growth. International Journal of Social Economics, 41(10), pp. 994-1010

[63] Zhuang, J., Liang, Z., Lin, and T., Guzman, F.D. (2007). Theory and Practice in the Choice of Social Discount Rate for Cost-Benefit Analysis: A Survey. ADB, Working Paper SERIES No. 94

[64] Zou, Y. (2006). Empirical studies on the relationship between public and private investment and GDP growth. Applied Economics, Taylor \& Francis Journals, 38(11), pp. 1259-1270.

[65] Zucchi, K. (2019). CAPM Model: Advantages and Disadvantages. https://www.investopedia.com/articles/investing/021015/advantages-anddisadvantages-capm-model.asp. 